\title{
Nomadic pastoralism in southern Iran
}

\author{
Hamid R Ansari-Renani ${ }^{1 *}$, Barbara Rischkowsky², Joaquin P Mueller ${ }^{3}$, Seyed M Seyed Momen ${ }^{4}$ and Sepehr Moradi ${ }^{1,5}$
}

\author{
* Correspondence: \\ ansarirenani@yahoo.com \\ ${ }^{1}$ Animal Science Research Institute \\ (ASRI), P.O. Box 31585-1483, \\ Karaj, Iran \\ Full list of author information is \\ available at the end of the article
}

\begin{abstract}
The nomadic pastoralist system in Baft district in Kerman province is well known in Iran for producing cashmere from Raeini goats. However, there is little information on the production system. Interviews were carried out with 30 Siahjel nomad families of Raen origin in proximity of about $20 \mathrm{~km}$ to Baft city in 2010 to characterise the production system in terms of family labour force, work sharing, livestock numbers, management and marketing practices, and diseases. The nomads move their livestock over large distances within the rangelands of the region from May to November, and the majority migrate south during autumn and winter. Of the nomad families, $87 \%$ live with and manage their animals together with one or more other related families. All household heads are males. All family members are involved in raising livestock; males and hired labourers dominate the physically harder jobs like shepherding and breeding, while women are involved in milking and caring. Of the animals, $80 \%$ are owned by adult or young unmarried males, none by daughters. Average proportion of goats and sheep per family flock are 89\% and $8 \%$, respectively, which indicates that Siahjel nomads mainly rely on goats. Adult breeding females constituted the largest group within the goat herds. The rationale for keeping a high number of male goats may be related to their greater production of cashmere. Diseases accounted for $57 \%$ of adult and $88 \%$ of young animal deaths. The most prevalent diseases were enterotoxaemia, foot-and-mouth disease, pneumonia, agalactia and diarrhoea. Animal sales, meat, cashmere and milk production are the major reasons for keeping goats. Rangeland is considered as the main source of feeding ( $85 \%$ of total annual feed intake); the remaining $15 \%$ is provided by stubble grazing. However, the herds do not produce enough meat, milk and cashmere to sustain the life of the nomad families, and thus, they often have to sell part of their stock which will further decrease their income.
\end{abstract}

Keywords: Nomad, Rangeland, Goats, Sheep, Dairy products, Cashmere, Wool

\section{Background}

Nomadic livelihoods are based on livestock and their products, which can be consumed or sold. Nomadic pastoralists often cover great distances with their livestock (Figure 1), following pasture availability (Blench 2001). The majority of nomadic pastoralists do not have permanent settlements and consequently use other mobile homes such as tents.

The pastoral nomads of Iran are scattered over an extensive habitat of over 963,000 $\mathrm{km}^{2}$. The general demographic dispersion pattern in nomadic societies of Iran indicates the following percentages of nomad population in the provinces of Fars (12\%), Kerman (9.6\%), Khuzestan (9.2\%) and West Azerbaijan (8.6\%). Overall, nomads 


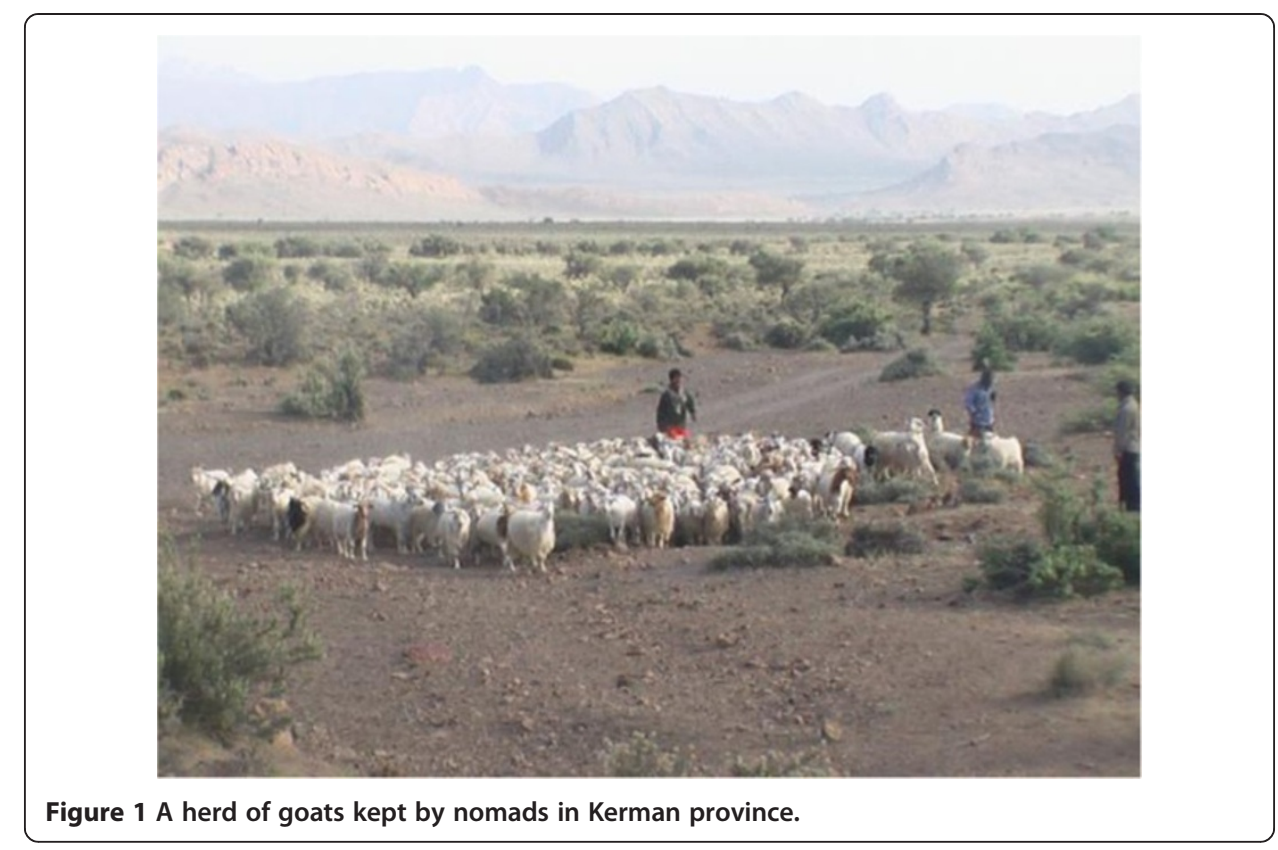

represent about 1.9\% of Iran's total population (Emadi 1995; Badjian et al. 2011). The nomadic livestock production systems in Iran have not received adequate attention regarding legal protection of land rights, extension support to improve animal breeding, animal nutrition and health, and regarding access to credit and market opportunities. Instead, the government has directed its efforts towards sedentarization of the nomads (Emadi 1995).

In the Persian language, nomads are known as ashayer. Historically, the pastoral nomads of Central Asia (e.g. Iran, Afghanistan and Pakistan) migrated in caravans annually following major routes; for example, from the central and southern deserts to highland pastures of the mountains of northern and western Iran during the summer, returning to the warmer desert areas during the winter. Nomadic systems of Iran are characterised by low population densities, displacement of livestock between grazing areas (cities and provinces) in different seasons, weak linkages to markets and public services and, for many, multiple co-resident family units (clusters) (two to five households staying together). Livestock is often the largest non-land asset they own and predominates as a source of livelihood. The nomads' knowledge of their physical environment and their livestock has been collected and refined by them over centuries.

Of the 25 million goats in Iran, 5 million are cashmere producing (Ministry of Agriculture 2004), and the remaining are meat- and milk-producing types. The main breeds of cashmere-producing goats are Raeini, Nadoushan, Birjandi, Abadeh and Abasabadi kept in Kerman, Yazd, South Khorasan, Fars and Razavi Khorasan provinces, respectively (Figure 2). Of all the goats, $40 \%$ are kept by nomads in about $59 \%$ of the total area of the country. The exact quantity of cashmere production and export from Iran is not known, but it can be estimated that five million cashmere goats produce about 2,000 tons of raw cashmere annually.

Cashmere is the fine, undercoat fibre (down) produced by cashmere goats in some of the most arid parts of Central Asia, including China, Mongolia, Iran and Afghanistan. Cashmere is a luxury fibre regarded as one of the most expensive natural fibres in the 

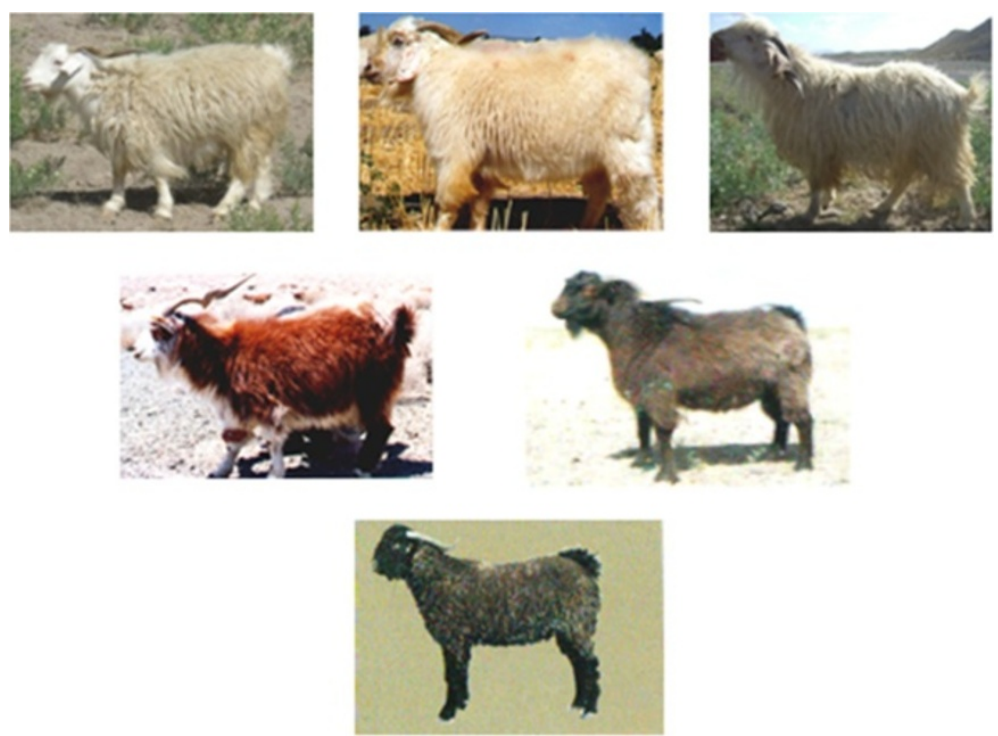

Figure 2 Main cashmere goat breeds of Iran: Raeini (first row), Nadoushan (second row) and Birjandi (third row).

world. The price of this luxury fibre is high but is subject to wide fluctuations in the international markets leading to price increases or decreases by $50 \%$ or more in a short period of time (Figure 3). The characteristics of cashmere such as hard-wearing durability, resilience or springiness, moisture absorption, comfort, fineness and smoothness make it ideally suited to many applications in the apparel and textiles.

Presently, data on the characteristics of nomadic pastoralists of Iran are very limited, in particular, on the extensive Raeini goat systems of Kerman Province. In order to

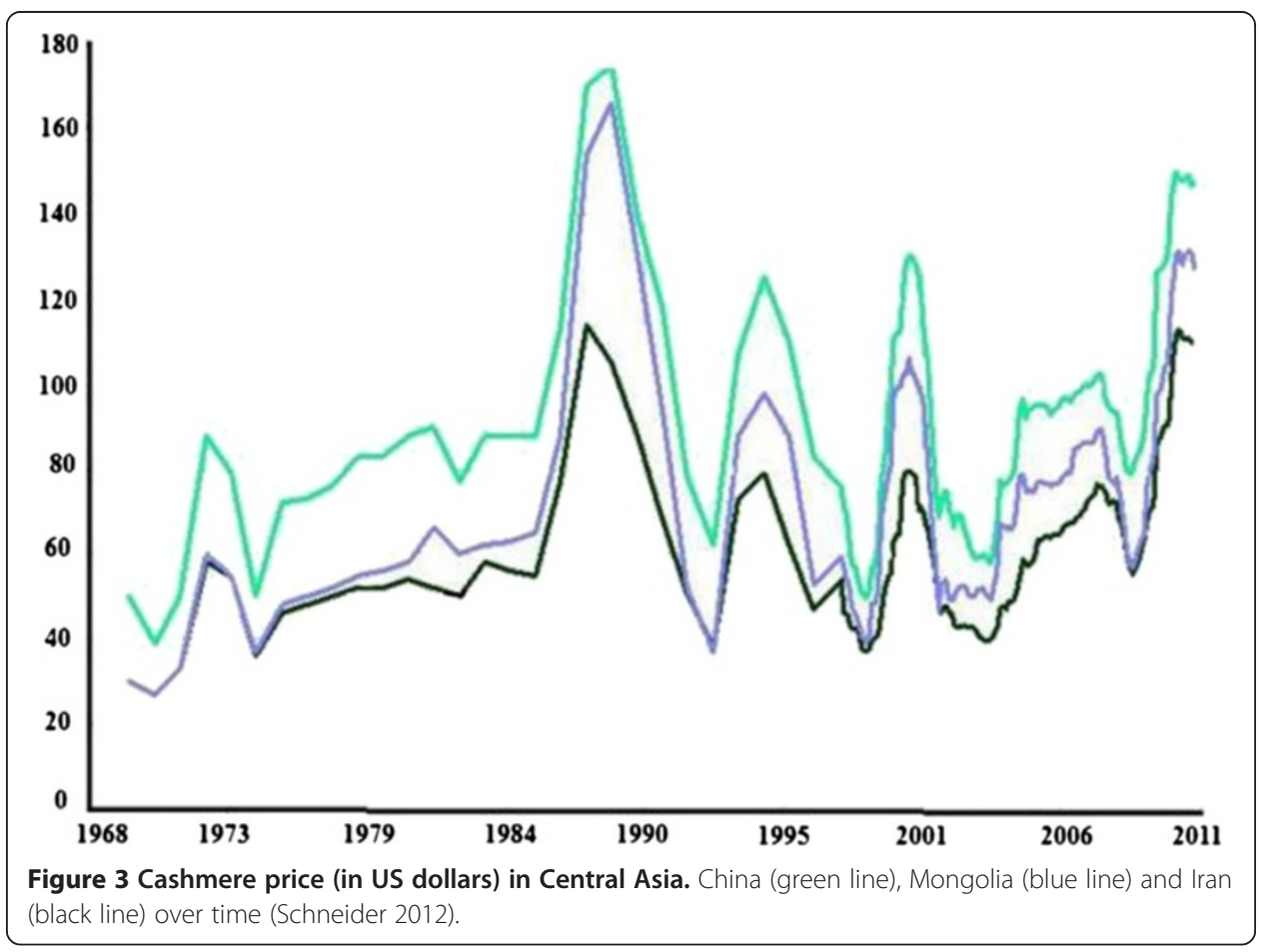




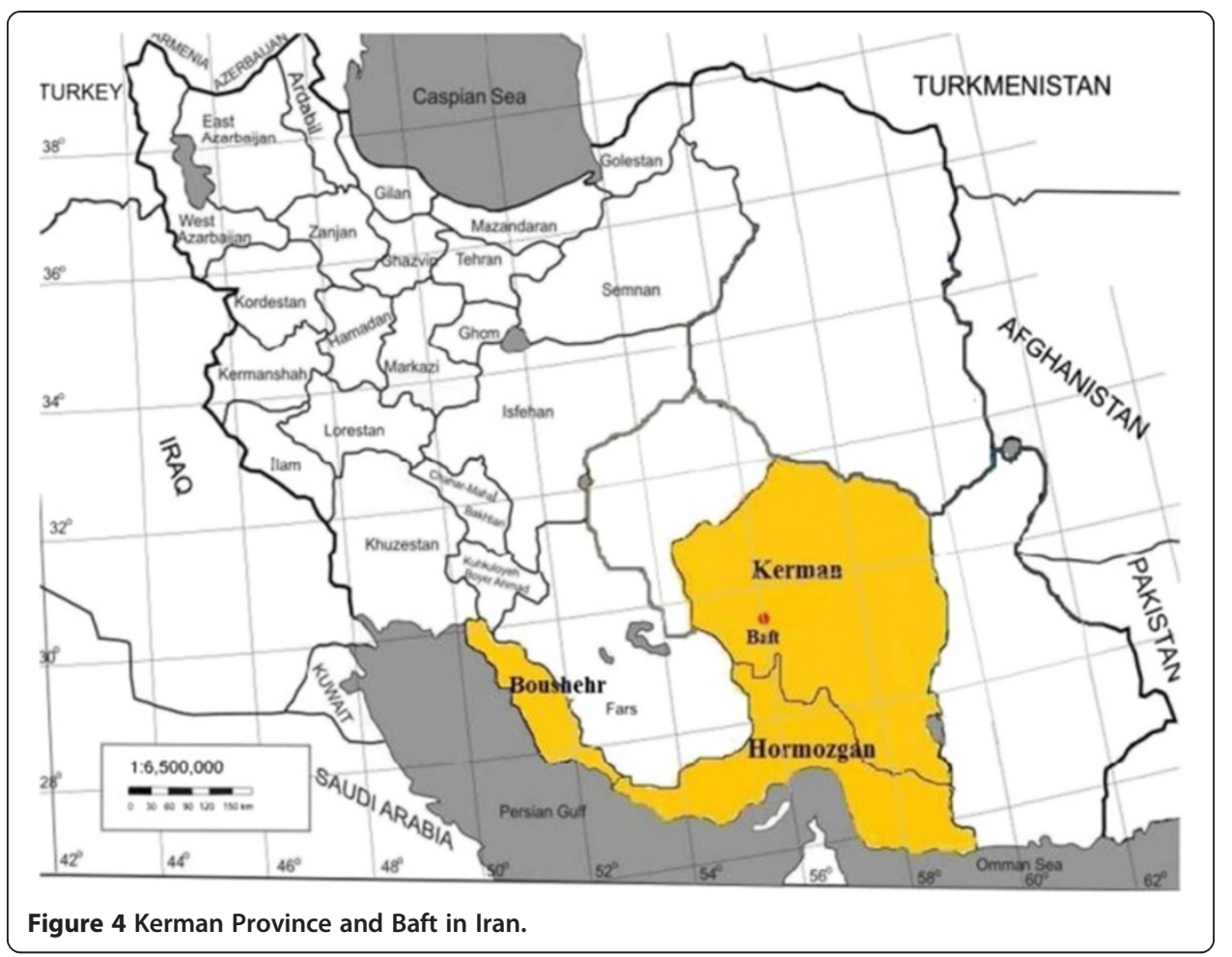

develop appropriate support services and policies to assist these pastoralists, this study characterises the Raeini pastoralist system based on formal questionnaires and field observations.

\section{Study area}

This study was undertaken in Kerman province, Baft region in the southern part of Iran (Figure 4). Kerman province is a highland region with $<250 \mathrm{~mm}$ annual rain. Summer is hot (up to $35^{\circ} \mathrm{C}$ ) and dry, and winter is moderate. Baft is a region in the southeast of

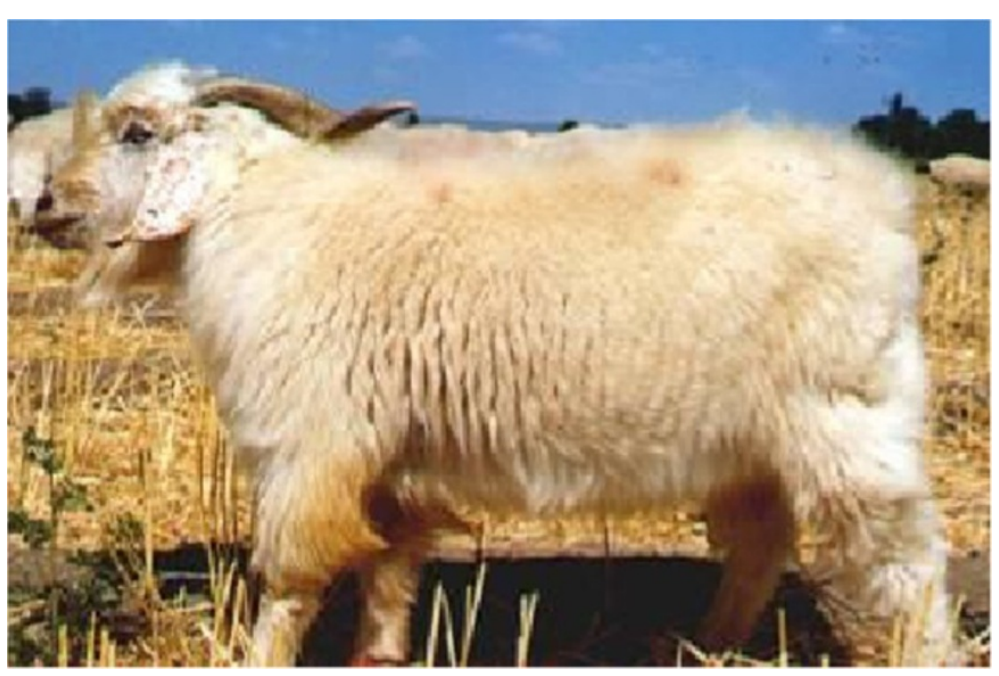

Figure 5 A typical male Raeini goat kept by nomads in Kerman province. 


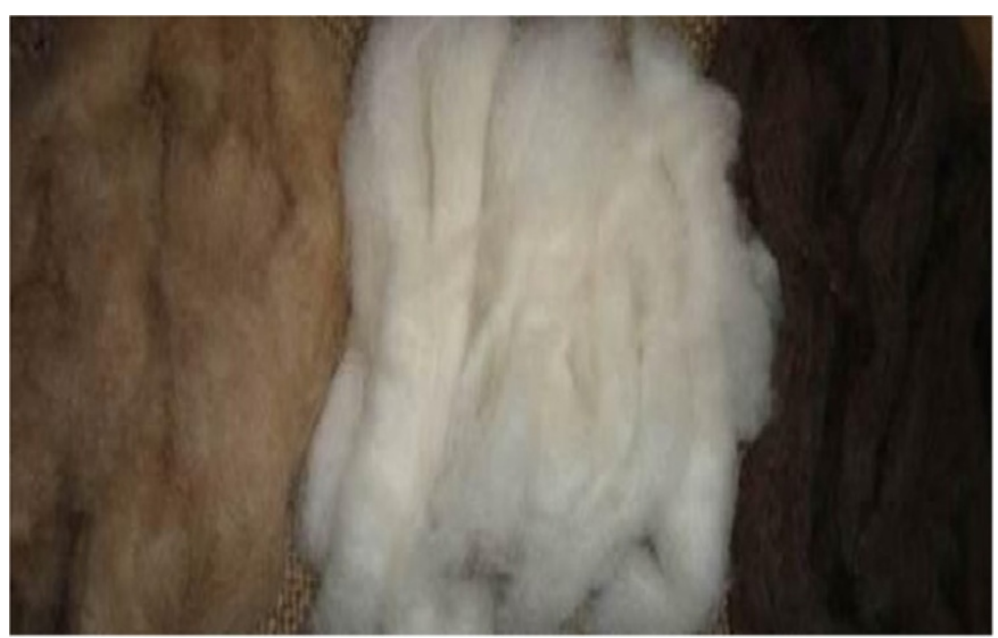

Figure 6 White, light and dark brown cashmere produced by Raeini goats.

Kerman province, which is $2,270 \mathrm{~m}$ above sea level with a latitude of $29^{\circ} 17^{\prime} \mathrm{N}$ and longitude of $56^{\circ} 36^{\prime} \mathrm{E}$. In this area, most nomad households belong to the Siahjel sub-tribe of the Raen tribe. This region has two main livestock breeds: the Raeini cashmereproducing goat and the carpet wool-producing Kermani sheep.

Male Raeini goats have an average live weight of $35 \mathrm{~kg}$ and females, $30 \mathrm{~kg}$ (Figure 5). They produce on average $507 \mathrm{~g}$ of cashmere of different colours (Figure 6) with averages of $56.5 \%$ down yield, $19.5 \mu \mathrm{m}$ (micron) fibre diameter and a staple length of 54.2 $\mathrm{mm}$ (Ansari-Renani et al. 2012). Kermani sheep produce on average $2.0 \mathrm{~kg}$ of wool with $70 \%$ efficiency, a staple length of $150 \mathrm{~mm}$ and a fibre diameter of $27 \mu \mathrm{m}$ (Sattari 1975).

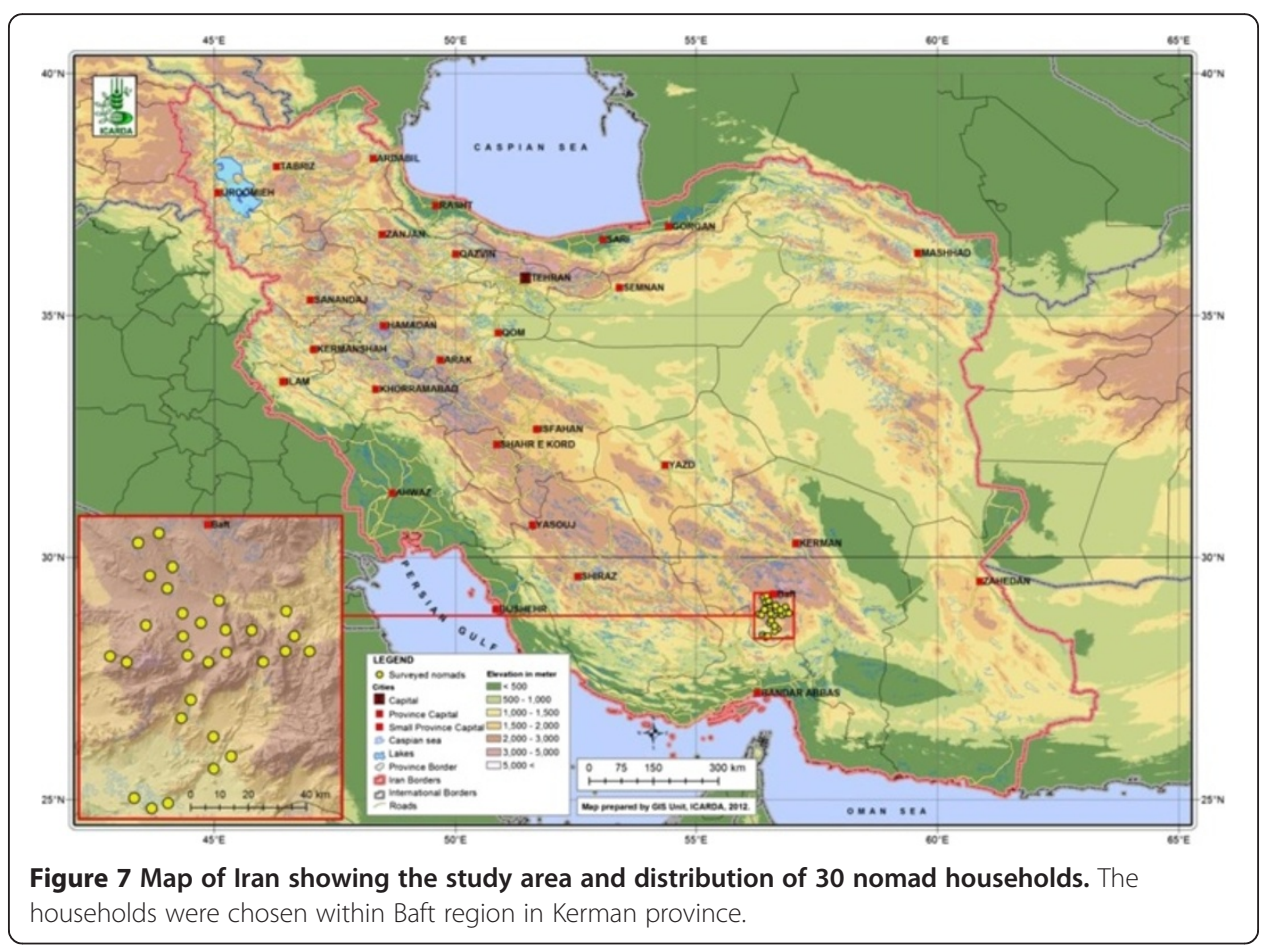


Table 1 Number of families moving together and livestock mobility

\begin{tabular}{lc}
\hline Characteristics & Percentage \\
\hline Number of families & 13 \\
Single & 47 \\
Two & 23 \\
Three & 10 \\
Four & 7 \\
Five or more & \\
Livestock mobility & 81 \\
Nomadic & 19 \\
Transhumance & - \\
Sedentary & \\
\hline
\end{tabular}

\section{Methods}

A total of 30 nomad settlements were chosen at random within $\pm 20 \mathrm{~km}$ of Baft city in Kerman province (Figure 7). Information was gathered primarily through in-depth interviews with men and women in the Persian language from January to July 2010. Four periods of six to seven days of fieldwork were conducted within the Baft region. Each interview lasted approximately three hours and consisted of about 50 predetermined questions. A structured questionnaire was completed for each individual family of settlement heads including family composition and labour allocation structure; herd structure and management, nutrition, health, breeding and reproduction; cashmere production, marketing; milk processing and dairy products. The responses to those questions were tallied, and the percentages of the various responses were calculated. Minimum, maximum, standard deviation and standard error values were measured using SAS package.

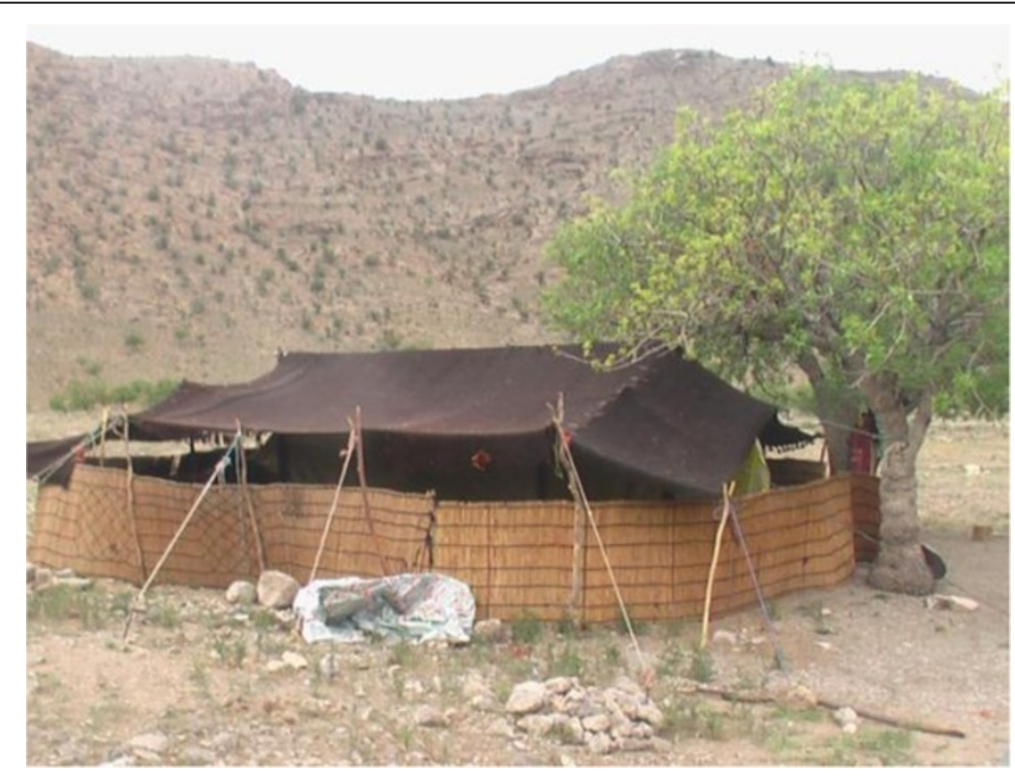

Figure 8 A single tent of only one household. 


\section{Results}

\section{Household and family structure}

According to the results, $87 \%$ of the nomad families stay and move together with other families, mostly closely related, to support each other in different occasions. Consequently, the tent settlements of Raen nomads consist of two to six households (Table 1 and Figure 8) and build a unit or 'cluster' (Figure 9). Ninety \% of these clusters manage their animals together to support each other and to share the cost of different livestock activities including shepherding, feeding, milking and health care. For example, joint management allows adult and young animals to be herded separately. Adult and young livestock are penned separately near the tent in circular-shaped pens made up of wood and fenced overnight (Figure 10), and they are milked by women and children in the morning before being taken out for grazing.

\section{Seasonal movements}

Of the nomad families, $81 \%$ use the Baft rangelands in spring and summer for grazing and migrate to the southern Persian Gulf provinces of Hormozgan and Bushehr in autumn and winter (Figure 4). These nomadic pastoralist households have no fixed homesteads and cover great distances with their livestock even within the Baft region, following pasture availability throughout the seasons. The other $19 \%$ of families show a regular seasonal movement between set areas within the Baft region. These transhumant pastoralists usually stay as a single family and do not integrate with other families. Their movement could be described as vertical, where pastures at high altitudes are used in summer and pastures in the lowlands are used in winter, or horizontal in the surroundings of Baft region. Consequently, the livestock density in Baft varies throughout the year, with the highest number of livestock and people in summer.

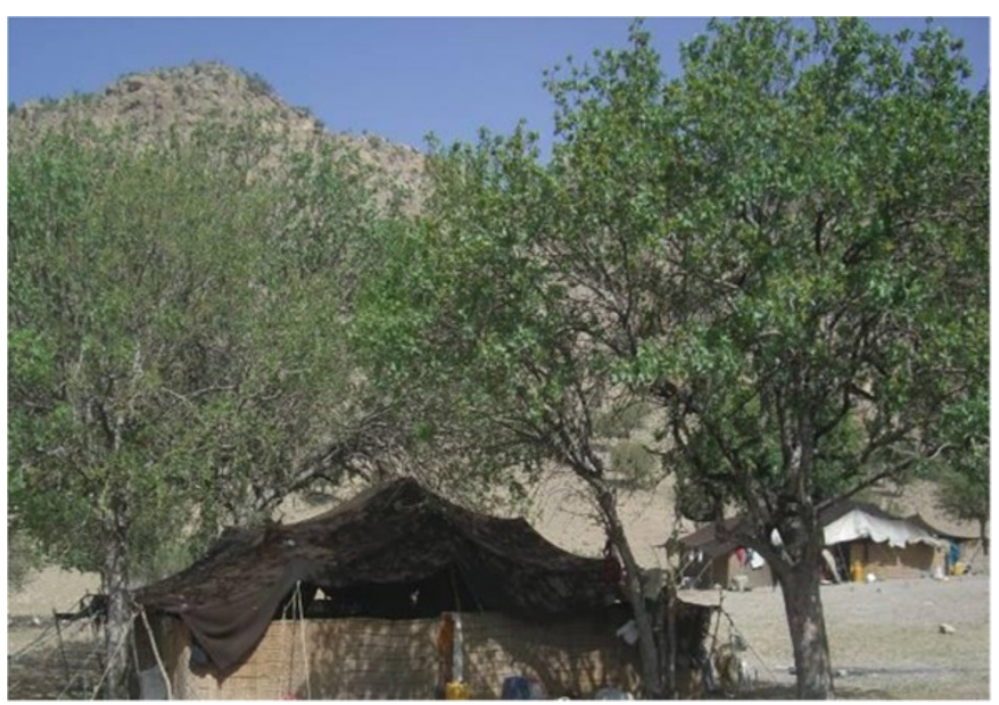

Figure $9 \mathrm{~A}$ tent settlement of two households forming a cluster. 


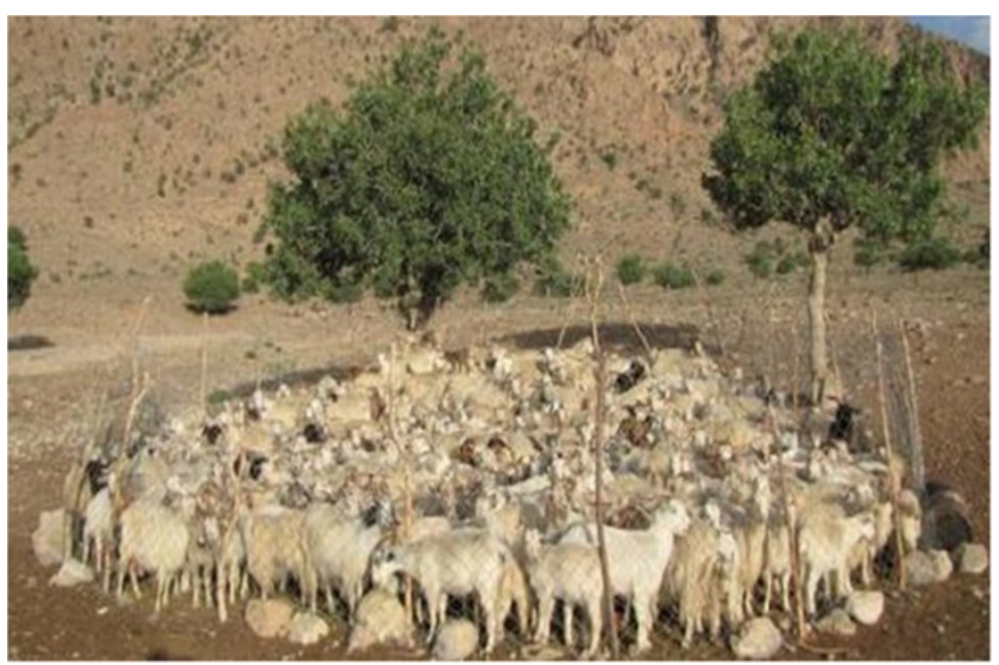

Figure 10 A typical Raeini cashmere goat herd kept in the fence.

\section{Labour force and work sharing}

All household heads are male; $47 \%$ are between 31 and 60 years old, $30 \%$ are older than 60 years and only $17 \%$ are 30 years old or younger. In total, $74 \%$ of the family members are between 15 to 65 years of age and only $6 \%$ and $20 \%$ are older than 65 or younger than 15 years of age, respectively. Male adult family members own most of the livestock, while girls and women do not own any (Table 2).

All family members are involved in raising livestock; men dominate the physically harder jobs like shepherding, shearing and breeding, and the women are more involved in feeding and caring for sick animals (Table 3 and Figure 11). The goats and sheep are milked by women, children and hired labourers. The share of hired farm labour is very high in shepherding, shearing, breeding and milking, although the family members could have done these tasks, suggesting that these members preferred other jobs over

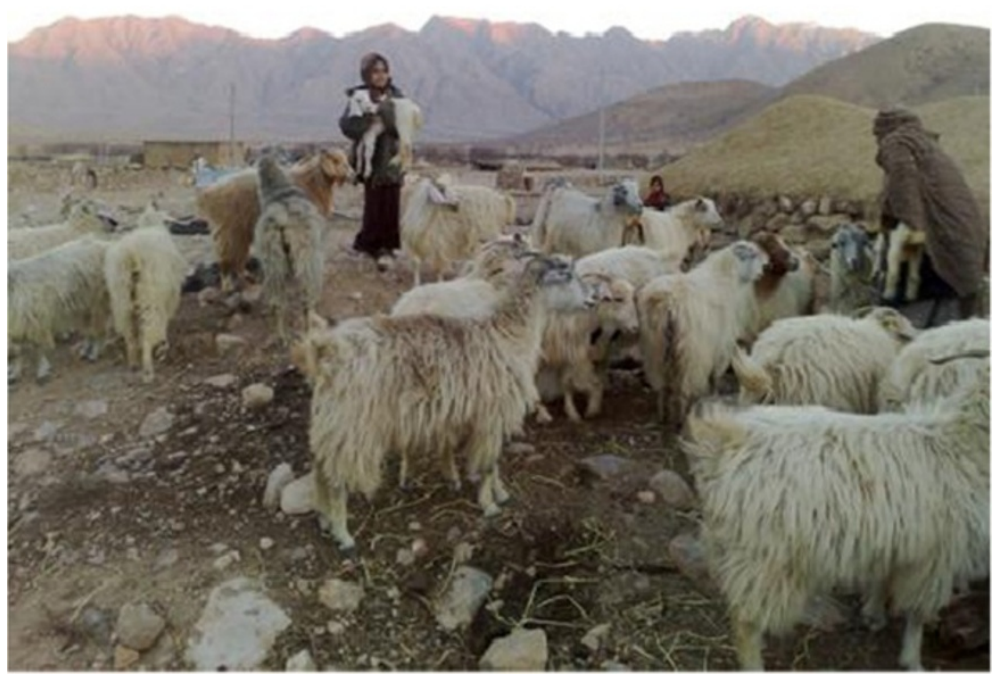

Figure 11 Nomad women taking care of Raeini goats. 
Table 2 Family structure and livestock population

\begin{tabular}{|c|c|c|c|c|c|c|c|c|c|c|c|c|c|c|c|c|}
\hline \multirow[t]{3}{*}{ Age groups } & \multicolumn{8}{|c|}{ Family members (\%) } & \multicolumn{8}{|c|}{ Livestock ownership (\%) } \\
\hline & \multicolumn{5}{|c|}{ Male } & \multicolumn{3}{|c|}{ Female } & \multicolumn{4}{|c|}{ Male } & \multicolumn{4}{|c|}{ Female } \\
\hline & (\%) & SD & SE & Range & $(\%)$ & SD & SE & Range & $(\%)$ & SD & SE & Range & $(\%)$ & SD & SE & Range \\
\hline$<15$ years & 11 & 12.8 & 2.3 & $0-50$ & 10 & 14.1 & 2.6 & $0-45$ & 3 & 9.1 & 1.6 & $0-100$ & 0 & 0 & 0 & 0 \\
\hline $15-65$ years & 36 & 19 & 3.4 & $7-86$ & 38 & 19.3 & 3.5 & 7-93 & 77 & 33.7 & 6.1 & $0-100$ & 20 & 29.8 & 5.4 & $0-50$ \\
\hline$>65$ years & 3 & 5.7 & 1 & $0-20$ & 2 & 5 & 0.9 & $0-20$ & & & & & & & & \\
\hline
\end{tabular}

livestock husbandry or that they were more qualified for other jobs elsewhere where they earned more.

\section{Livestock production and management}

Siahjel nomads of Raen origin rely mainly on goats but keep a small number of sheep. Average proportions of goats, sheep and equines (mainly mules and a few donkeys) per family are $89 \%$ (range 71 to 100), $8 \%$ (range 0 to 29 ) and 3\% (range 0 to 27), respectively. Mules and donkeys are kept for transportation.

The respondents commented that these percentages change under certain circumstances such as harsh climate conditions and drought. They also reported that extended drought periods, which were very common in the last decade, contributed towards lower reproductive efficiency and thereby lower herd productivity and resulted in a reduced herd size.

Adult breeding females constituted $44 \%$, the largest group within the goat herds; the female yearlings made up 12\% (Table 4). Bucks and male yearlings constituted $8 \%$ and $7 \%$ of the herds, respectively. The high proportion of adult and yearling males $(15 \%)$ in relation to adult and yearling females (56\%) is a disproportionate buck ratio (1:3.6). Contrarily, the proportion of kids and yearlings in the total goat herd is relatively low, which may indicate a low reproductive rate. Weaning is usually done at about 5 months; average age of goats at sexual maturity is 9 months followed by first kidding at 14 months.

The rationale for keeping herds with such a large number of males is apparently related to their greater production of cashmere, as also suggested by Miller (2000) and Marius et al. (2004). Male goats tend to produce more cashmere weight and yield than

Table 3 Work sharing between family members and hired labour by livestock management activities

\begin{tabular}{|c|c|c|c|c|c|}
\hline \multirow[t]{3}{*}{ Activities } & \multicolumn{4}{|c|}{ Family members involved (\%) } & \multirow[t]{3}{*}{ Male hired labour* (\%) } \\
\hline & \multicolumn{2}{|c|}{ Adults (>15 years) } & \multicolumn{2}{|c|}{ Children (<15 years) } & \\
\hline & Male & Female & Male & Female & \\
\hline Purchasing animals & 83 & 17 & - & - & - \\
\hline Selling animals & 83 & 17 & - & - & - \\
\hline Shepherding & 32 & - & 5 & - & 63 \\
\hline Breeding & 56 & - & - & - & 44 \\
\hline Caring for sick animals & 35 & 35 & - & - & 30 \\
\hline Feeding & 27 & 27 & 21 & 2 & 23 \\
\hline Milking & 4 & 32 & 22 & 7 & 35 \\
\hline Shearing & 53 & 2 & - & - & 45 \\
\hline
\end{tabular}

*Hired male labourers are older than 15 years except for milking where $8 \%$ were younger than 15 years. 
Table 4 Total number, percentage of goats and sheep of different age and sex

\begin{tabular}{|c|c|c|c|c|c|c|}
\hline \multirow[t]{2}{*}{ Age groups } & \multicolumn{4}{|c|}{ Proportion/herd (\%) } & \multicolumn{2}{|c|}{ Population/herd (Head) } \\
\hline & Average & SD & SE & Range & Average & Range \\
\hline \multicolumn{7}{|l|}{ Goat } \\
\hline Buck (Nari) & 8 & 5.3 & 1 & $3-29$ & 22 & $4-90$ \\
\hline Doe (Torshiz) & 44 & 10.5 & 1.9 & $30-65$ & 122 & $80-240$ \\
\hline Castrated male (Akhte) & 5 & 4.9 & 0.9 & $0-16$ & 14 & $0-100$ \\
\hline Male yearling (Chavosh) & 7 & 5.2 & 0.9 & $0-20$ & 19 & $0-90$ \\
\hline Female yearling (Gise) & 12 & 3.7 & 0.7 & $6-20$ & 32 & $15-60$ \\
\hline Male kid (Kare) & 10 & 5.4 & 1 & $0-19$ & 28 & $0-75$ \\
\hline Female kid (Kare) & 14 & 6.1 & 1.1 & $5-38$ & 39 & $13-110$ \\
\hline \multicolumn{7}{|l|}{ Sheep } \\
\hline Ram (Ghooch) & 6 & 3.5 & 0.6 & $0-14$ & 3 & $0-10$ \\
\hline Ewe (Meesh) & 45 & 23.2 & 4.2 & $0-64$ & 25 & $0-100$ \\
\hline Male yearling (Shishak) & 4 & 3.2 & 0.6 & $0-14$ & 2 & $0-6$ \\
\hline Female yearling (Kavor) & 18 & 10 & 1.8 & $0-25$ & 10 & $0-50$ \\
\hline Male kid (Barre) & 7 & 8 & 1.5 & $0-29$ & 4 & $0-10$ \\
\hline Female kid (Barre) & 20 & 10.5 & 1.9 & $0-30$ & 11 & $0-40$ \\
\hline
\end{tabular}

Words in Italic are local terms.

female goats (Ansari-Renani et al. 2012). This matches the explanation given by the herd owners that adult male goats tend to yield more and better quality cashmere than females since pregnant animals channel energy to the offspring, which reduces the growth and quality of the cashmere. Pregnant goats also tend to have a higher rate of shedding of cashmere than males (Ansari-Renani et al. 2001, 2011). During average years with sufficient fodder, many nomads do not want to sell their animals as they believe in maximising the number of animals owned as a safeguard against losses.

Adult male goats also tend to have lower rate of losses (Table 5). Of all adult goat losses, $67 \%$ are females and $33 \%$ are males. It is well documented that mortality rates of females, especially lactating animals, increase during drought periods (Stroebel et al. 2008). Female animals remain in a relatively poor condition and rarely have the opportunity to gain weight. Highly fertile animals which give birth regularly are even at

Table 5 Causes (\%) of losses in adult and young livestock and distribution (\%) of losses by sex

\begin{tabular}{|c|c|c|c|c|c|c|c|c|}
\hline \multirow{2}{*}{$\begin{array}{l}\text { Factor/Age group } \\
\text { Mortality rate }\end{array}$} & \multicolumn{4}{|c|}{ Adult } & \multicolumn{4}{|c|}{ Young } \\
\hline & (\%) & SD & SE & Range & (\%) & SD & SE & Range \\
\hline Male & 30 & 20.1 & 3.7 & $0-80$ & 46 & 16 & 2.9 & $0-70$ \\
\hline Female & 67 & 24.2 & 4.4 & $0-91$ & 52 & 18 & 3.2 & $0-80$ \\
\hline Castrate & 3 & 10.1 & 1.8 & $0-40$ & 2 & 6.6 & 1.2 & $0-34$ \\
\hline \multicolumn{9}{|l|}{ Cause of death } \\
\hline Diseases & 57 & 43 & 7.8 & $0-100$ & 88 & 30.6 & 5.6 & $0-100$ \\
\hline Predators & 36 & 36.9 & 6.7 & $0-100$ & 11 & 24.4 & 4.5 & $0-100$ \\
\hline Poisoning & 5 & 15.2 & 2.7 & $0-50$ & 0 & 0 & 0 & 0 \\
\hline Accidents & 0 & 0 & 0 & 0 & 0 & 6 & 1.1 & $0-33$ \\
\hline Unknown & 2 & 9.1 & 1.6 & $0-50$ & 0 & 0 & 0 & 0 \\
\hline
\end{tabular}


higher risk. On the other hand, males enhance economic survival which enables the family to sell these animals.

The larger the size of the herd, the higher is the percentage of old animals. These old livestock, although less productive, still produce cashmere and kids, though less frequently. Thus, nomads' livestock are assets and for sustaining their social status, which explains why nomads keep livestock well beyond the optimal age for production or commercial slaughter.

Goats are most frequently mated in late June/July and kidding takes place at the end of November till January (Table 6). The kidding period at the beginning of winter is associated with low temperatures and low feed availability in the rangelands of Baft area. Hence, to avoid losses, at the end of autumn, most nomads migrate to warmer areas of southern provinces adjacent to the Persian Gulf.

Contrary to intensive sheep and goat systems of production in which early weaning of lambs and kids is practised and all the milk and milk products are consumed by humans, there is no early weaning system in the nomadic system, where sheep and goats are generally low milk producers.

Poultry are kept in more than 95\% of nomad farms (on average 35 hens per farm, range 10 to 50). Ten out of thirty families own other poultry species, among them turkey, from which they keep on average five birds. During migration, poultry are kept in wooden baskets for easier transport. The nomads also keep large, fierce choupan (shepherd) breed of watch dogs for protection of the family and the herd.

\section{Livestock and health management}

Disease, predators and poisoning accounted for 57\%, 36\% and 5\% of adult animal deaths, and only $2 \%$ of deaths were for unknown reasons (Table 5). Disease, predators such as wolves and jackals, and accidents accounted for $88 \%, 11 \%$ and $1 \%$, respectively, of young animal deaths. Such uncontrollable loss of animal changes from year to year, causing growth and decrease in herds in a typically unstable manner (Goldstein and

Table 6 Seasonal features of goat management

\begin{tabular}{|c|c|c|c|c|c|c|c|c|c|c|c|c|}
\hline & Dec & Jan & Feb & Mar & Apr & May & Jun & Jul & Aug & Sep & Oct & Nov \\
\hline Mating ${ }^{1}$ & ** & ** & & & & & & & $* * *$ & $* * *$ & & \\
\hline Pregnancy & $* * *$ & $* * *$ & $* *$ & $* *$ & $* *$ & $* *$ & $* *$ & & & $* * *$ & $* * *$ & $* * *$ \\
\hline Kidding & & $* * *$ & $* * *$ & & & $* *$ & $* *$ & & & & & \\
\hline Lactating & $* * *$ & $* * *$ & $* * *$ & $* * *$ & $* * *$ & $* * *$ & ** & $* *$ & & & & \\
\hline Shearing & & & & & $* * *$ & & & & & $* *$ & & \\
\hline Grazing & * & * & $* *$ & $* * *$ & $* * *$ & $* * *$ & $* * *$ & $* * *$ & $* * *$ & $* * *$ & $* * *$ & * \\
\hline Stubble feeding & $* * *$ & $* * *$ & $* * *$ & & & & & & & & & $* * *$ \\
\hline Concentrate feeding & ** & * & * & & & & & $* *$ & & & & $* *$ \\
\hline Antiparasite treatment & & & & & $* * *$ & & & & & $* * *$ & & \\
\hline Main seasons & \multicolumn{3}{|c|}{$\begin{array}{c}\text { Winter, wet } \\
\text { and frosts }\end{array}$} & \multicolumn{3}{|c|}{$\begin{array}{l}\text { Spring, warm } \\
\text { and dry }\end{array}$} & \multicolumn{3}{|c|}{$\begin{array}{l}\text { Summer, hot } \\
\text { and dry }\end{array}$} & \multicolumn{3}{|c|}{$\begin{array}{c}\text { Autumn, cool } \\
\text { and wet }\end{array}$} \\
\hline
\end{tabular}

* Less frequent.

** - Middle frequent.

***- Most frequent.

1 - Bucks and does run together year round. 


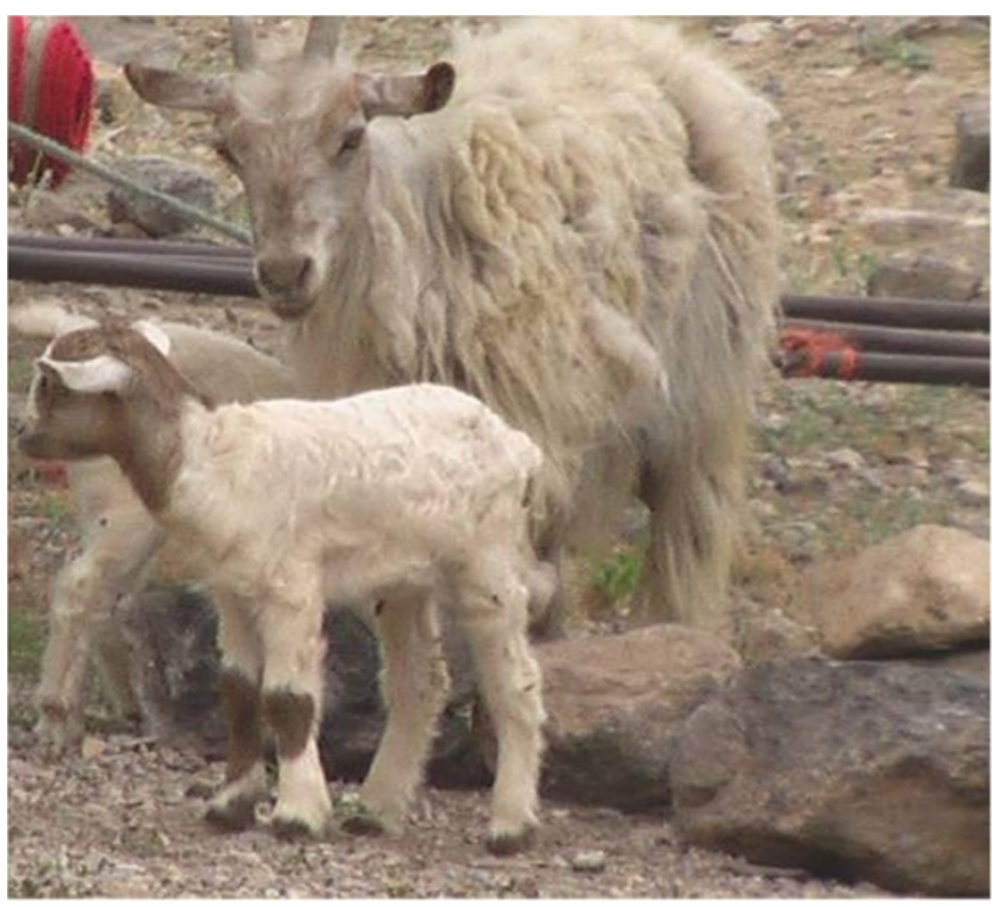

Figure 12 Newborn and sick animals are often kept together at the tent.

Beall 1990; Miller 1998, 2000). According to the nomads, horses, mules and donkeys are grazing unattended and are thus subject to predation by wolves and jackals.

Among the losses of young animals caused by diseases, the most prevalent diseases were diarrhoea (58\%), pneumonia (40\%) and foot-and-mouth disease (2\%), and the most prevalent diseases among adults were enterotoxaemia (49\%), foot-and-mouth disease (26\%), pneumonia (23\%) and agalactia (2\%).

Every nomadic region has its own governmental and private veterinary centre, reporting to the District Veterinary Administration. These centres are responsible for dealing with nomad livestock diseases and deaths of their respective region. Several vaccinations, e.g. against foot-and-mouth disease, are compulsory but free of charge during state campaigns. The veterinary centres also provide other privately paid services in case of emergencies.

Many of the nomads' animal management practices have a direct positive impact on the incidence of disease among their livestock. Some of the most significant practices

Table 7 Ranking in descending order of importance of keeping goats

\begin{tabular}{|c|c|c|c|c|c|c|}
\hline \multirow[t]{2}{*}{ Reasons for keeping } & \multicolumn{3}{|c|}{ Male animals } & \multicolumn{3}{|c|}{ Female animals } \\
\hline & $\begin{array}{l}\text { Number of } \\
\text { farmers }\end{array}$ & Ranking & $\begin{array}{c}\% \text { of } \\
\text { importance }\end{array}$ & $\begin{array}{l}\text { Number of } \\
\text { farmers }\end{array}$ & Ranking & $\begin{array}{c}\% \text { of } \\
\text { importance }\end{array}$ \\
\hline Cashmere production & 30 & 5 & 33 & 30 & 6 & 25 \\
\hline Milk production & - & - & - & 30 & 5 & 21 \\
\hline $\begin{array}{l}\text { Selling and meat } \\
\text { consumption }\end{array}$ & 30 & 4 & 27 & 30 & 4 & 18 \\
\hline Breeding purposes & 28 & 3 & 20 & 29 & 3 & 14 \\
\hline Wealth, status and saving & 2 & 2 & 13 & 7 & 2 & 15 \\
\hline Social activities & 28 & 1 & 7 & 14 & 1 & 7 \\
\hline
\end{tabular}


include reproduction management, the isolation of diseased animals, grazing and migration patterns. The nomad women know that infections of the udder can spread from one animal to another during milking and try to wash their hands with water between milking animals. Both men and women help at animal births. Women often explained that they are better than men at this since they have smaller hands, which is good for repositioning the foetus within the birth canal.

Newborn and young animals are often kept together at the tent with the women and children until they are old enough to go out to pasture with the herd. Animals that are diseased are likewise kept at the family tent, effectively isolated from the herd (Figure 12), so chances that infection will spread throughout the herd are thus reduced. When young animals are still nursing, the herd returns to the tent at least once each day to allow them to nurse.

The surgical technique of cutting the scrotum open with a knife and pulling the testicles is the common method of castration. The animals are usually castrated within their first year of life, often by six months of age. Nomads castrate their animal during

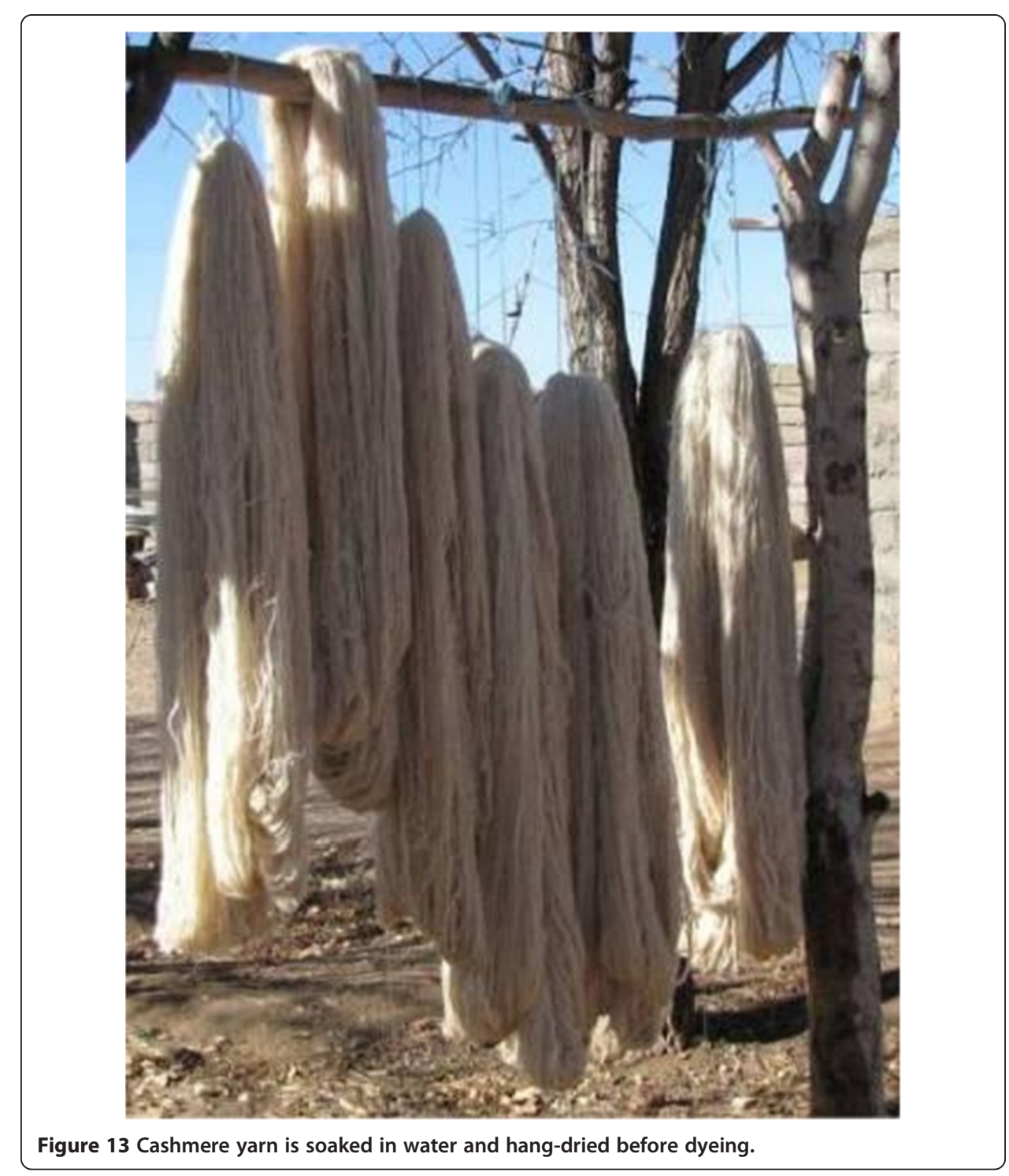




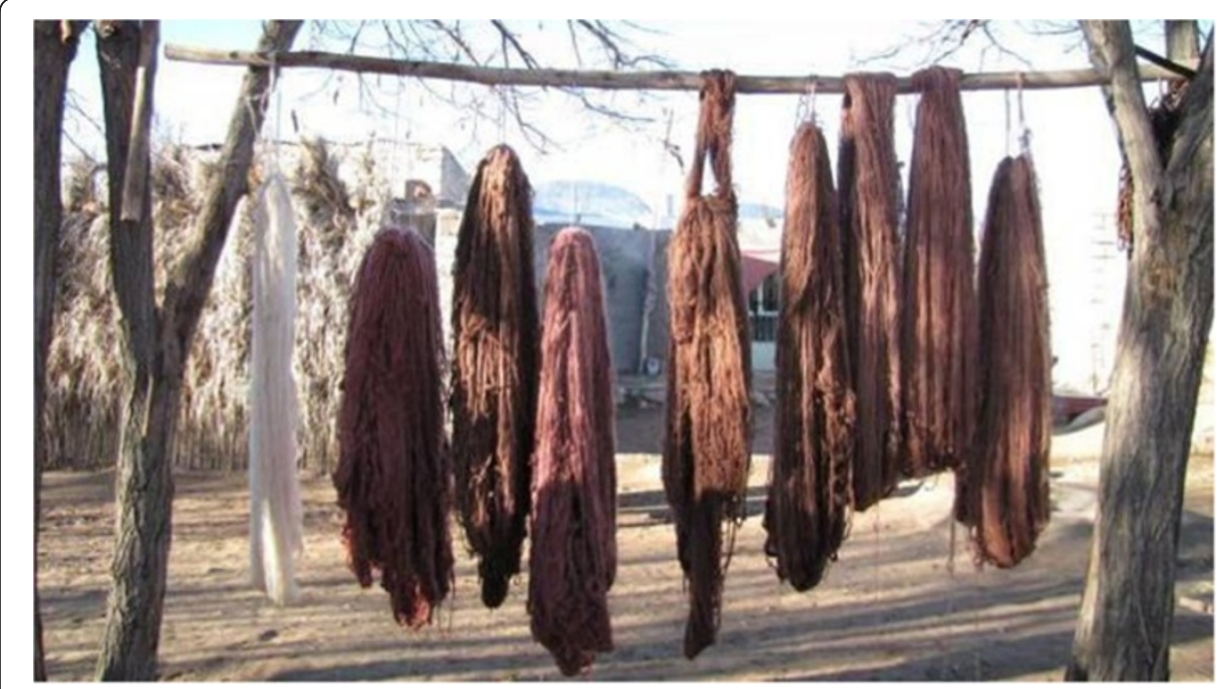

Figure 14 Cashmere yarn is dyed using natural dyes such as Henna, Rubbia and walnut husk. Dyed yarn is cooled, washed, rinsed and hanged to dry.

the cool months of the spring and autumn to reduce the chances of infection being spread by flies and other insects.

\section{Commercial livestock products}

Nomad goat pastoralists in Baft are more commercially oriented than nomads in other parts of Iran, as cashmere, milk and meat are given more priority for production than animal breeding and social status (Table 7). Goat coarse hair is spun and woven into tent material, ropes and blankets. The raw cashmere is usually sold to dealers and sometimes dyed using natural dyes (Figures 13 and 14) and spun into items for home use (Figures 15 and 16) using different spinning wheels and drop spindles (Figures 17 and 18). Traditionally, sheep and goat hides were used to make shoes or boots, but

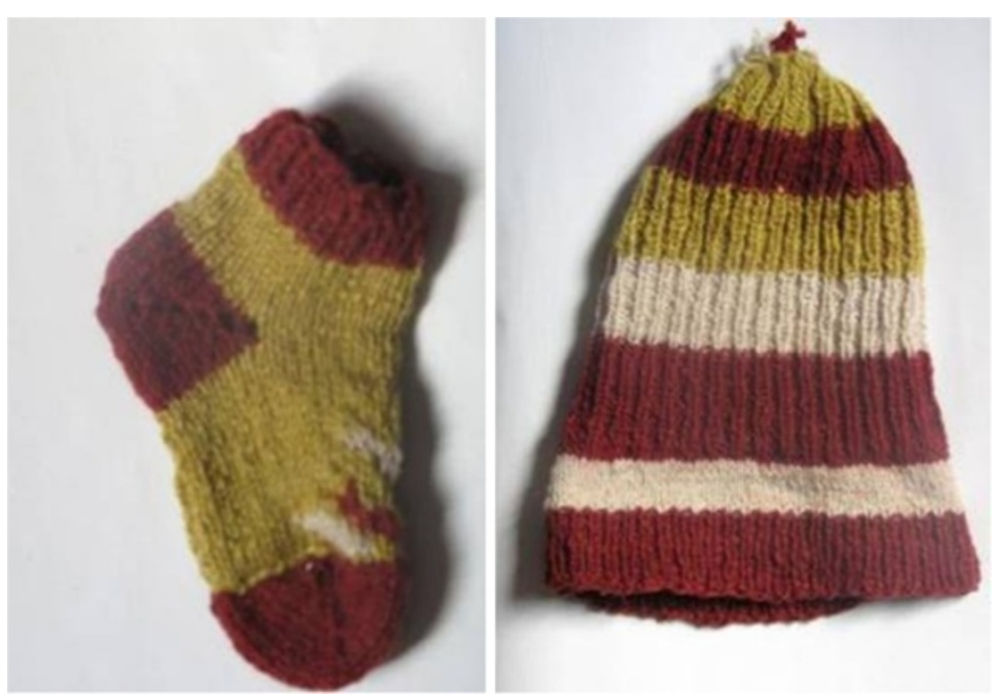

Figure 15 Hat (kolah) and sock (jourab). 


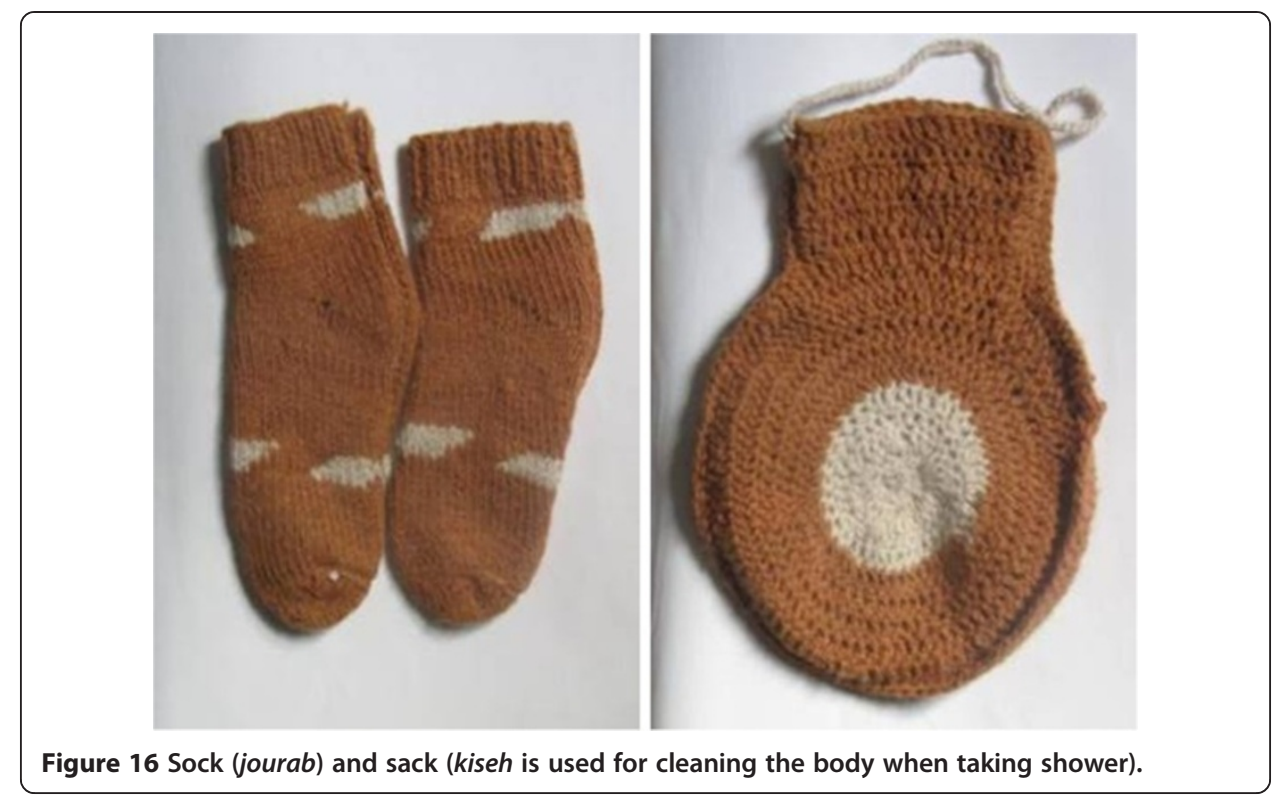

nowadays, most nomads prefer to buy shoes, which, although of lower quality, avoid labour.

Nomads do not have access to standard financial markets, including banks. Livestock offer an alternative for storing their savings or accumulated capital as a 'living savings account' (Randolph et al. 2007). This living savings account can be sold and converted into cash as needed and provides an instrument of liquidity as well as an alternative form of insurance for the family. In addition, livestock has the advantage that it can be sold at any time during the year (Vandamme et al. 2010), unlike crops which are highly seasonal.

\section{Dairy products}

Traditionally, Raen nomads consume more milk in their diets than meat. In fact, they often express a dislike for killing and trading animals. The majority of the families milk some of their animals for home use, but very few families milk all the animals, mainly

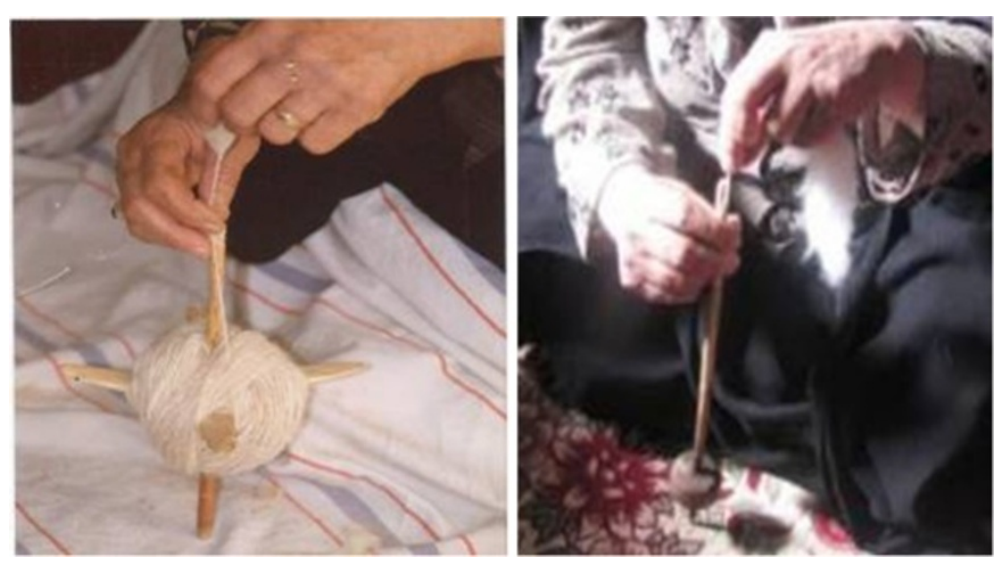

Figure 17 Two types of traditional drop spindles. 


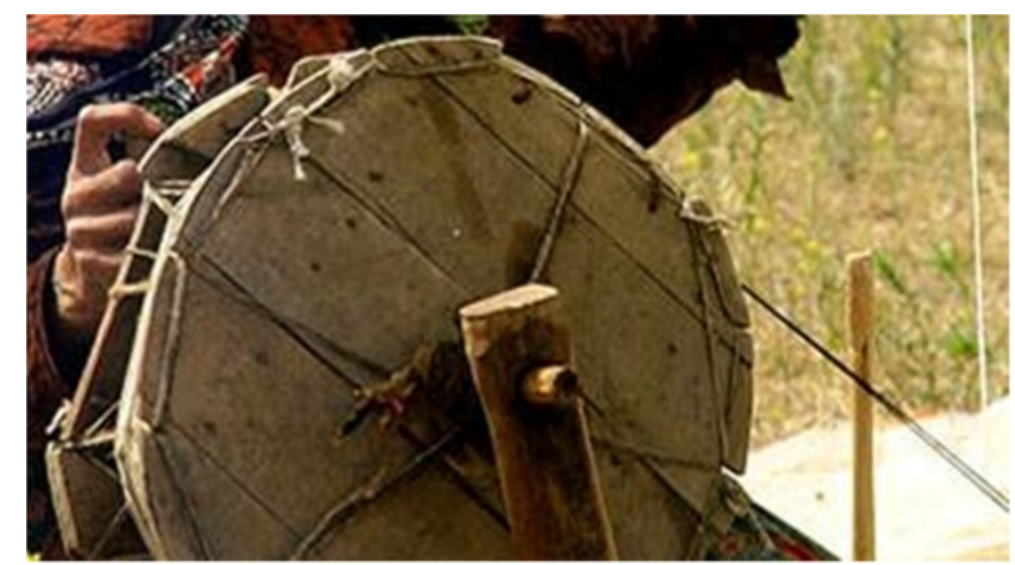

Figure 18 Traditional spinning wheel.

due to a shortage of labour. Of the total milk, about one third is consumed fresh and the rest is processed into dairy products. Using traditional methods, wives process the milk into butter and yoghurt for immediate use and ghee and hard, dry curds for storage. Most of the products are used for home consumption, but occasionally, some are given as presents.

Milk processing by Raen nomads includes several stages that are described here, using the nomads' terms (Figure 19). Milk is simply filtered into a pot, heated and allowed to cool. A small amount of yoghurt is added to the cooled milk as a starter. The pot is covered with a piece of cloth for 14 to 16 hours to keep the milk warm for proper preparation of yoghurt. Yoghurt can be consumed or further processed. Yoghurt (maust) is transferred to an inverted cattle or sheep skin (toolom or mashk) (Figure 20) which acts as a churn. Water is added to the churn containing yoghurt at a ratio of 1:1. The churn is then suspended by a tripod and rocked back and forth until butter

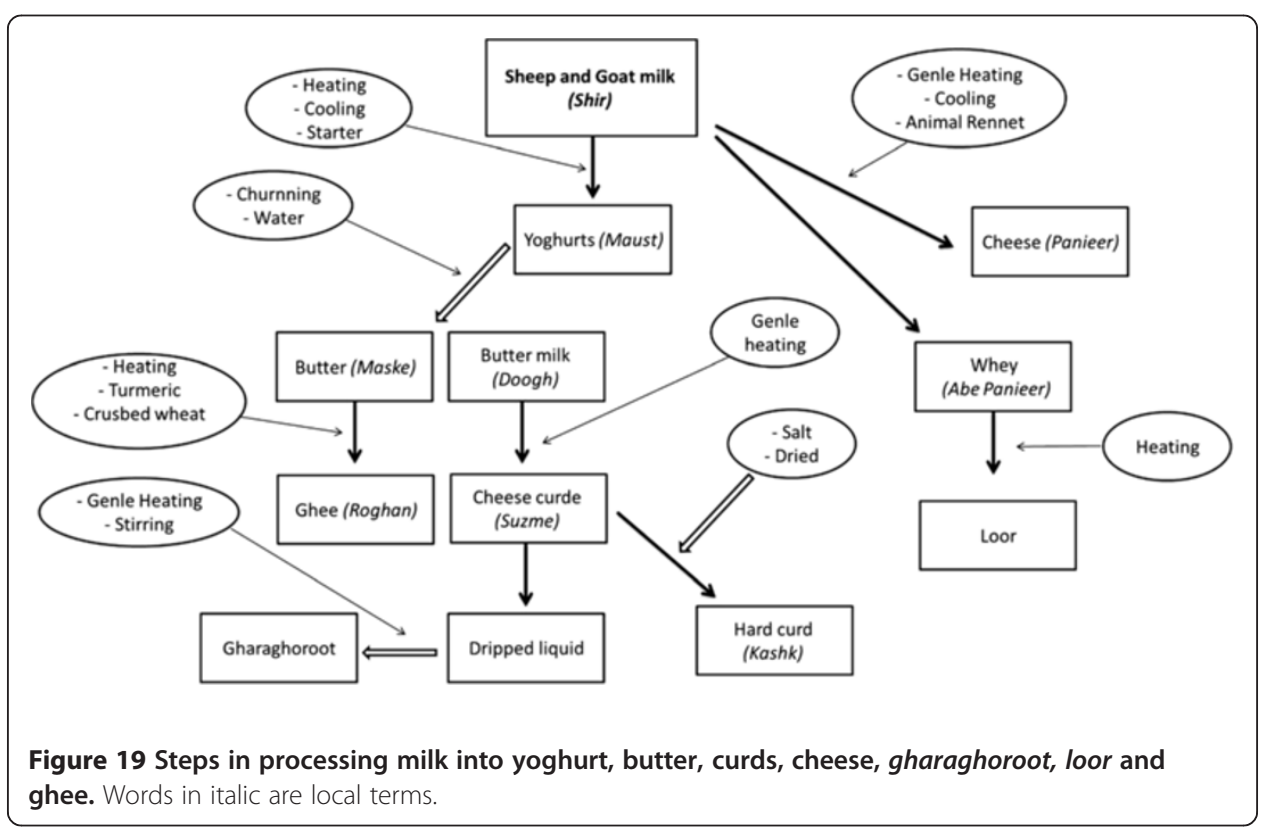




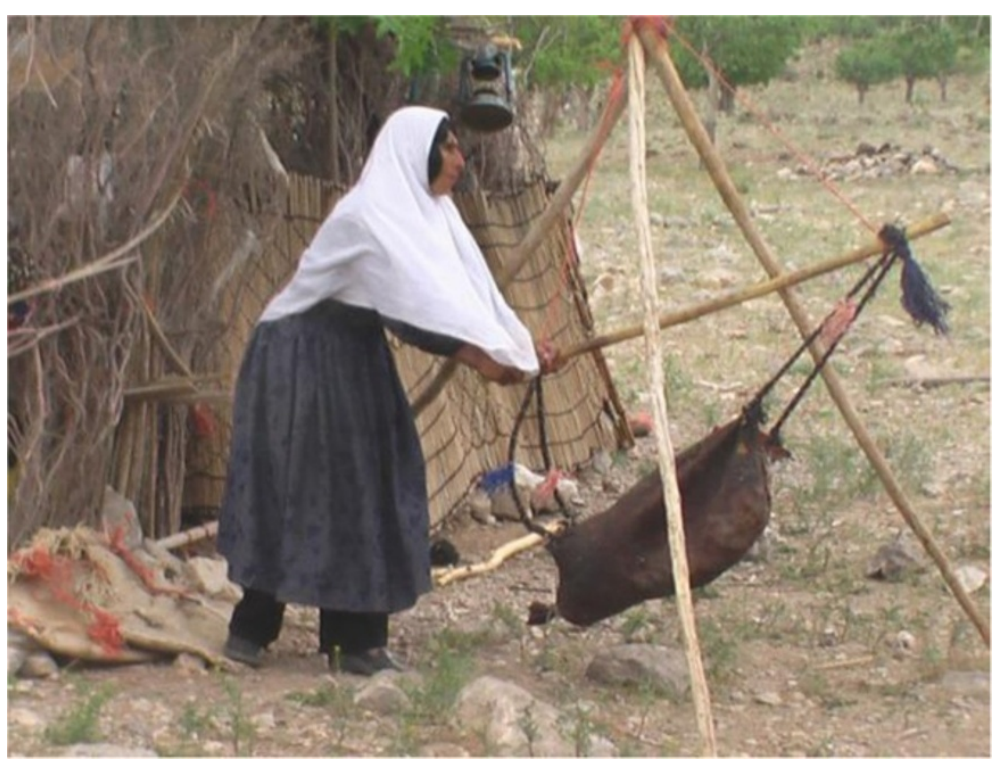

Figure 20 Inverted sheep skin (mashk) is used to make different dairy products.

granules form. The butter (maske) can be scooped out by hand, or the buttermilk can be drained off by pouring.

The making of butter and processing the buttermilk into hard, white curd (kashk) are basically the same techniques used by different nomad tribes of Iran. After butter is removed, the remaining buttermilk (doogh) may be consumed or further processed into hard white cheese curds. Buttermilk is placed in a pot and gently heated on a low flame to make cheese curds (suzmeh). Curds are put into a porous textile cloth sack and kneaded with a handful of salt while the remaining liquid continues to drip out. The curds (kashk or ghoroot) are shaped into balls, sun-dried and stored, becoming rockhard with time. Dripped liquid can be heated while a wooden scoop is used to stir the heating liquid to make a soured brownish substance called gharaghoroot which is used as a paste in making different stews. Ghee or clarified butter is made by removing almost all the water from the butter by gently heating the butter and stirring it continuously in a pot to which salt and turmeric are added.

To make cheese (paneer), milk is placed in a pot and gently heated. Animal rennet which is locally made from calf abomasum (called maye paneer) is added to the heated milk. Milk is allowed to coagulate overnight. Cheese is transferred to a textile sack and allowed to remain for about eight to ten hours to drip all the water or whey (abe paneer). Brine (saline solution 22\%) is added to the dripped, coagulated cheese and allowed to remain for 18 to 24 hours. Cheese is kept in a container of brine (11\%) for further use. Whey is placed in a pot and gently heated to make loor which can be consumed for breakfast.

\section{Marketing of live animals}

The price of live animals is usually determined by the sex, size and condition of the animal, although due to lack of a marketing infrastructure in the nomadic areas, nomads feel that they are subjected to lower prices offered by the buyer. The proportion of 
Table 8 Reasons for selling animals

\begin{tabular}{lc}
\hline Reasons & Percentage \\
\hline Too heavy & 22 \\
Very old & 19 \\
Too many males/females & 20 \\
Health condition & 19 \\
Availability of feed & 20 \\
\hline
\end{tabular}

nomads buying animals is very low; the reason is that they often depend on their existing animals to reproduce and increase their herd size.

Animals are sold to abattoirs or butchers directly either for cash needed for income or for culling unwanted livestock. Meat production is almost exclusively for sale. Home slaughtering for own consumption and sales to neighbours or relatives occurs only occasionally; hide sales therefore play a minor role for income. On average, $41 \%$ of animals are sold because they are too old, while $39 \%$ of animals are sold based on their health condition and lack of feed availability in different seasons (Table 8). Only $20 \%$ of animals are sold because the herd is overpopulated.

\section{Harvesting and marketing of cashmere}

Nomads only shear their animals once a year in mid-spring, depending on the weather conditions. Of these nomads, $82 \%$ shear in April and May, while $11 \%$ and $7 \%$ shear in March and June, respectively. Nomads use double-blade scissors known as docard (Figure 21) to shear goats. On average, it takes about 11 minutes to shear a sheep or a goat. Of these nomads, $11 \%$ can shear each animal in less than eight minutes, while $61 \%$ shear in more than ten minutes.

As a result of fibre follicle inactivity, a sequential, bilateral-symmetric pattern of cashmere shedding initiates in Raeini cashmere-producing goats on the neck (Figure 22)

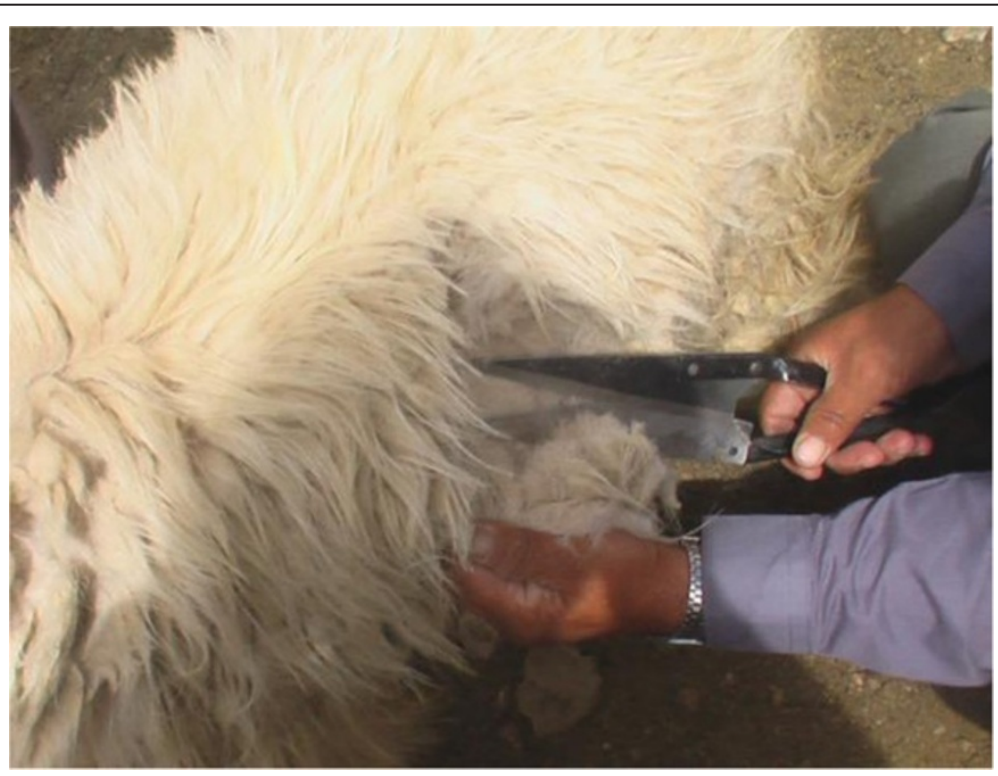

Figure 21 Double-blade scissors known as docard are used to shear the goats. 


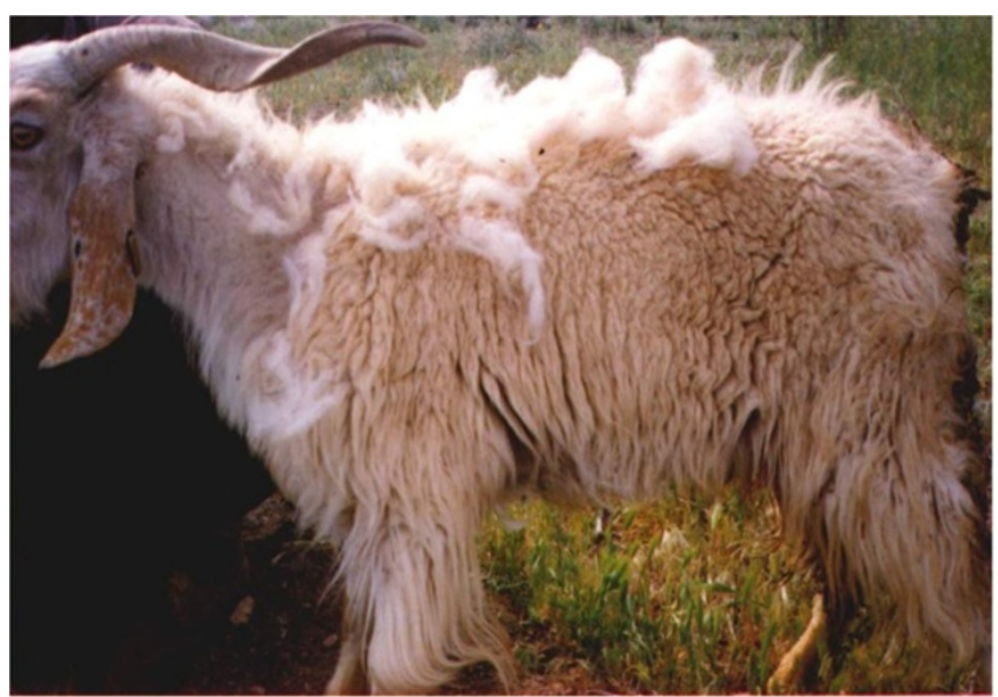

Figure 22 Cashmere shedding initiates on the neck in Raeini goat.

and proceeds in a wave posteriorly towards the rump (Figure 23) with up to a five- to six-week delay between the two sites (Ansari-Renani 2001; Ansari-Renani et al. 2011, 2012) (Figures 22 and 23).

In order to harvest the maximum weight of cashmere, the optimal time for a single shearing of cashmere goats would be at the end of the winter season before follicle inactivity becomes substantial or before onset of shedding. At this stage, goats are in their poorest body condition due to the cold weather and very limited feed availability. Thus, it is important from the point of the welfare of the goats that some hair is left on the animal after cashmere harvesting as this hair provides an essential protective layer against adverse weather conditions. The use of either machine or hand shearing at this point in time which removes the entire fleece poses a

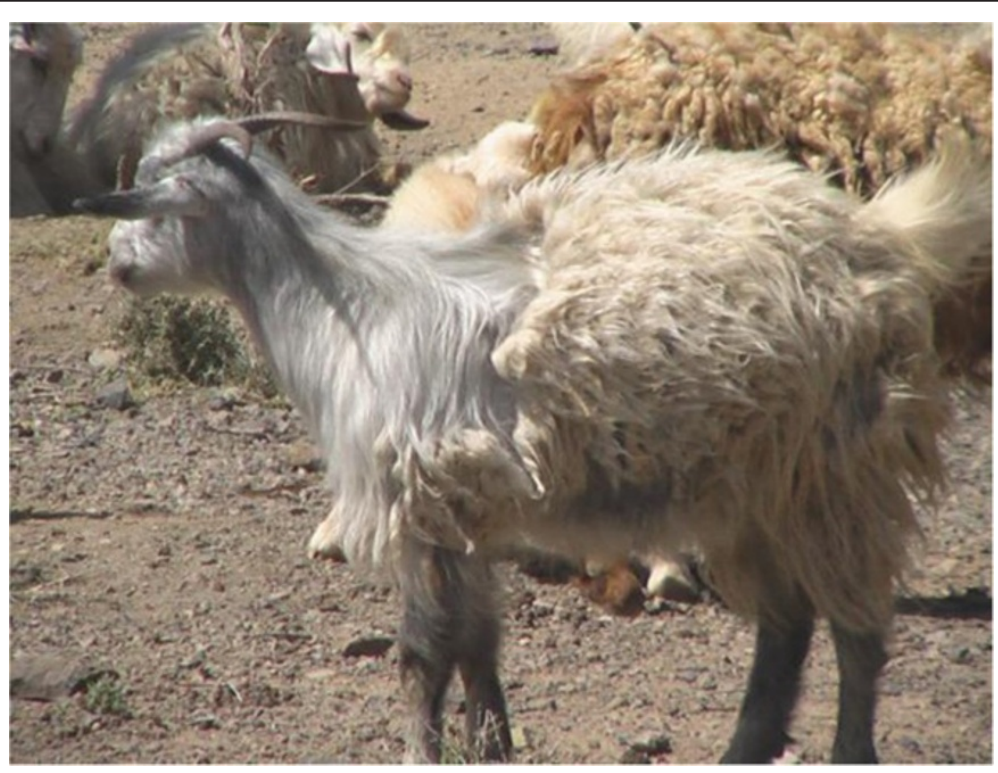

Figure 23 Cashmere shedding proceeds in a wave posteriorly towards the rump. 
serious threat and cannot be recommended under such conditions. On the other hand, the current practice of nomad cashmere producers to shear their goats in mid-spring using double-blade knives is wasting valuable cashmere. The use of combs (Figure 24) or the collection of clumps of cashmere retained in the fleece after the onset of shedding would reduce cashmere loss during the shedding season. The unshed cashmere could be sheared in mid-spring when adverse weather conditions are over.

Among these nomads, $60 \%$ sell the goat fleeces immediately after shearing, while $40 \%$ sell at a later date when the price is higher. Sheared cashmere is usually stored in plastic bags and stored in a dry and cool environment. Among those interviewed, $41 \%$ and $32 \%$ of nomads received marketing information from traders and neighbouring farms, while $14 \%$ and $13 \%$ received their information from livestock associations (such as the Agriculture Organization in Baft city) and markets, respectively. Nomad goat owners usually sell the whole fibre, unsorted, containing both rough outer hair and the inner fine cashmere to local or travelling merchants or traders.

The sale of cashmere provides a substantial part of the nomads' cash income, but because prices fluctuate according to world market demand, such income can also fluctuate significantly from year to year. Almost all households shear their few sheep for home use to make handmade carpets and crafts. Therefore, sheep wool does not add immediate cash to the nomads' income.

\section{Livestock feeding}

Rangeland is considered the main source of livestock nutrition (85\%), while grazing crop stubbles contribute about 15\% to the livestock food source (Table 9). Stubble fields

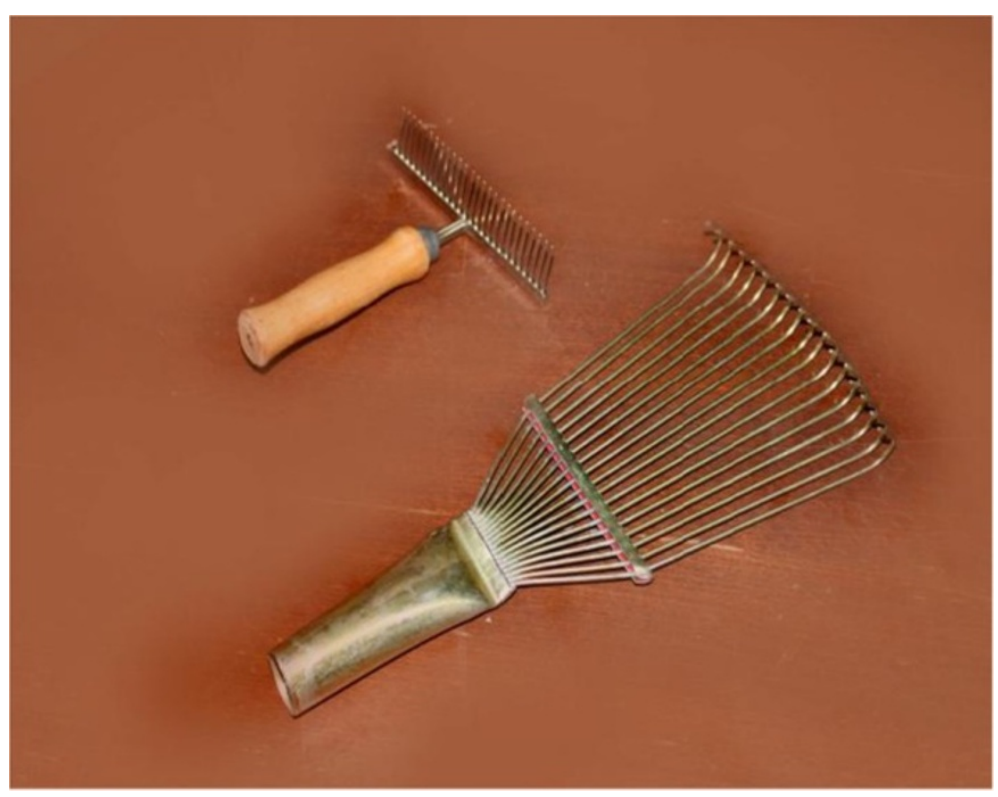

Figure 24 Long and short combs. 
Table 9 Sources of feed, type of grazing land and grazing system of goats

\begin{tabular}{lc}
\hline Grazing systems & Percentage \\
\hline Source of feed & \\
Range & 15 \\
Stubble & 38 \\
Type of grazing land & 23 \\
Open grass land & 31 \\
Tree covered & 8 \\
Bush/Shrub & \\
Stone covered & 67 \\
Grazing & 33 \\
Goats alone & \\
Together with other species & \\
\hline
\end{tabular}

are mainly available in autumn. Goat bucks, does, yearlings and kids are supplemented with barley mainly during the winter season when feed is scarce in rangelands.

In most cases, the ratio between the high price of feed inputs and lower price of livestock product outputs provides insufficient incentives for the nomads to purchase inputs for developing intensive production systems (Rueda et al. 2003). Relevant feed types used to handfeed animals include crop by-products, straw and hay, grains and vegetables. Wheat and barley straw, and bran are the most commonly fed crop by-products. Sedentary farmers allow the nomads to graze their herds on the crop stubble left in the fields or in the orchards. This agreement provides food for the nomads' livestock while providing manure to fertilise the farmers' fields and orchards.

Raen nomads often herd more than one species of livestock. Consequently, the rangeland can be better exploited through a mix of grass (grazed by sheep) and intermediate roughage eaten by goats (Hofmann 1989). This way, livestock density can be increased considerably compared to keeping only one livestock species. In addition, risk of livestock losses is buffered, whether losses are due to disease or extreme environmental conditions. The annual migrations that most Raen nomads undertake and the generally extensive grazing patterns of the herd help to lower the incidence of internal parasites and certain diseases such as anthrax.

\section{Rangeland use}

While $38 \%$ and $31 \%$ of herds are grazed on open or bush/shrub grassland, 23\% and $8 \%$ of herds are grazed on tree-covered or stone-covered grasslands (Table 9). Nomads do not own or rent any land but use communal grasslands. Of the goat herds, $67 \%$ are grazed separately and 33\% are grazed together with sheep (Table 9). The herders explained that tree-covered grazing areas which include wild oak trees are the preferred rangeland, as the nutritive value of leaves consumed by animals complements the grass very well.

The nomads recognise the relationship between soil type and plant growth and put this knowledge into systematic use. Light sandy soils in the dune areas allow faster sprouting of grass and herbs than the heavy soils of the plain areas. Thus, the first light 
rains in the spring produce fresh grass much earlier on the sandy soils, and the nomads will move there accordingly.

Prolonged droughts or environmental extremes can be disastrous to the livestock. In some years, early and heavy snowfall is followed by low air temperature which prevents snow from melting. The livestock is then unable to reach the forage under the snow, and consequently, many animals die.

\section{Watering}

Of these herds, 36\% receive water from wells, while the other herds are supplied with water from various sources such as rivers, pipes, springs, rain and small dams (Table 10). While only $4 \%$ of herds have access to water directly at the grazing rangeland, the majority of nomads (72\%) supply their animals with water at a distance of up to $5 \mathrm{~km}$ (Table 10).

Most herd owners water their animals twice $(71 \%)$ or even three times daily $(24 \%)$ (Table 10). When drinking more frequently, goats increase feed intake and metabolic rate (Brosh et al. 1986), and therefore, milk, meat and fibre production will be enhanced. In dry years with poor pasture and water availability, and as a result, low milk production, sheep and goats are not milked and the kids and lambs are allowed to suckle all the milk (Maltz et al. 1983). Of these herds, $88 \%$ have access to clean water, but $12 \%$ are forced to use muddy water; none uses salty or smelly water.

\section{Conclusions}

The nomads themselves stress the fact that life in this nomadic region has become very hard due to current economic situations. Our results indicated that more than $90 \%$ of nomad family household heads have relied on other means of subsistence and additional jobs to compensate for unpredictable losses of livestock. The Raen nomads have emphatically noted that their livestock do not produce enough milk, cashmere and meat to sustain them throughout the year. Thus, the nomads have to often sell part of their stock, which is their capital. This can have dire consequences, since they constantly are under threat of losing part of their herds due to environmental factors, and smaller herd size makes it more difficult to rebuild a herd after a disaster. As a result of lacking support, as well as increasing environmental challenges such as degradation of rangelands and droughts, the nomadic pastoralists have been declining in number in the last decades and have been forced to search for wages in urban settings.

Table 10 Source of water, distance to the nearest source and frequency of watering of animals

\begin{tabular}{lccccc}
\hline Source & $\%$ & Distance & $\%$ & Frequency & $\%$ \\
\hline Well & 36 & At farm & 4 & Once/day & 5 \\
River & 20 & $<1 \mathrm{~km}$ & 10 & Twice/day & 71 \\
Pipe & 20 & $1-5 \mathrm{~km}$ & 62 & Three times/day & 24 \\
Spring & 16 & $6-10 \mathrm{~km}$ & 10 & & \\
Rain & 6 & $>6 \mathrm{~km}$ & 14 & & \\
Dam & 2 & & & & \\
\hline
\end{tabular}


The pastoral areas of Kerman province support only a small human population that is widely spread across physically isolated locations. The nomads are less educated and tend to experience poorer service delivery and declining employment opportunities than in other regions. They also lack a political voice because they are remote from the seats of power. These factors limit their access to basic infrastructure, undermine their ability to obtain social services and, in some cases, reduce their rights to own or access land. Traditional livestock production and grazing management strategies have already been altered in the past several decades in Baft region, resulting in more marketoriented goat production.

The goal for Iran's agriculture has been to increase grain production especially wheat, which has resulted in the conversion of large areas of marginal rangeland to crop land as rain-fed grain production, which conflicted with the goal of maintaining rangeland ecosystem health and stability. It is concluded that the pastoral nomad areas have been negatively affected by three sets of policy-related issues: population pressures, market distortions, and industrial uncertainties. These factors have interacted with the adoption of new technologies, including the opening of additional water wells and animal health programmes, supplementary winter fodder/feed from agricultural by-products and cultivation of improved pasture which, in many cases, has led to an increase in livestock numbers, thus leading to rangeland degradation.

\section{Recommendations}

Growing demand for healthy (e.g. organic) livestock products of meat, milk, skin and fibre from local, domestic, regional and global markets will continue to be the main driver of a nomadic livestock system. Nomadic pastoralists can play an important role in a necessarily sustainable production of livestock products if investments are targeted and implemented in areas of most probable positive returns. Policies and investments are needed to be pro-nomads, and emphasis is needed to empower them and to develop their capacities to participate more fully in the modern economy.

Sustained nomadic pastoralism will depend upon finding solutions to the constraints. These solutions will include technical and institutional innovations to serve nomadic pastoralists. Research needs to be responsive to what is changing, in order to maximise research contribution to sustaining nomadic livestock systems. Future scenarios of pastoralist livestock systems can be used to explore important uncertainties and assess the impact of different technologies, policies, and institutions on livestock production systems and on the nomad people. Monitoring indicators of key drivers over time, as well as their impacts, can build the capacity of research and development organisations to respond effectively in a rapidly changing context.

To achieve these goals requires a deeper appreciation for the complexities associated with the role that rangeland and livestock play in the livelihood strategies of the nomads and in nomadic household nutritional and health dynamics. It also means recognising the context in which nomad households operate, especially with respect to their participation primarily in informal markets and their weak capacity in the public sector. Decisions about nomadic pastoralism must take into account 
both socio-economic and environmental dimensions. The different perspectives on these two dimensions need to be bridged to achieve consensus on priorities.

Our lack of knowledge about nomadic pastoralists implies the need for carefully designed and empirical research, including environmental and social considerations. Such research could possibly be combined with a systems modelling approach to untangle the complexity and lead to practical guidelines and best practices for nomadic livestock intervention design.

Some lessons have already been learned and successes exist, but further research is needed to (1) develop more effective grazing and nutrient management of rangelands, (2) develop more efficient livestock management and (3) determine the biological and socio-economic implications of the transition to more effective production. At the same time, we need to move beyond the conventional state-led provision of services and develop new institutional innovations and strategies that explicitly consider the needs of the nomads.

Competing interests

The authors declare that they have no competing interests.

\section{Authors' contributions}

HRAR contributed to the design of the project, collection of data, acquisition, analysis and interpretation of data and the drafting of the manuscript. BR and JPM contributed to the design of the questionnaire, the analysis and interpretation of data; and revised the manuscript. SM contributed to the analysis of data. SMSM contributed to collection of data using questionnaire forms. All authors read and approved the final manuscript.

\section{Authors' information}

HRAR a small ruminant specialist at the Animal Science Research Institute (ASRI), Karaj, Iran. BR is a small ruminant specialist at the International Center for Agricultural Research in the Dry Areas (ICARDA), Addis Ababa, Ethiopia. JPM is a small ruminant breeder at the Instituto Nacional de Tecnología Agropecuaria (INTA), Bariloche, Argentina. SM is a Ph. D student doing his studies on small ruminants at Mashad University, Iran. SMSM is a M. Sc. graduate specialist on small ruminant nutrition.

\section{Acknowledgments}

We are grateful for the financial support provided by the International Fund for Agricultural Development (IFAD) for this study. Our gratitude is extended to the Iranian Animal Science Research Institute, the Agriculture and Natural Resources Center of Kerman province and ICARDA office in Tehran for the support of this project. Special gratitude is also given to all the cashmere producers in Baft region who shared and contributed their knowledge and information with the authors.

\section{Author details}

${ }^{1}$ Animal Science Research Institute (ASRI), P.O. Box 31585-1483, Karaj, Iran. ${ }^{2}$ International Center for Agricultural Research in the Dry Areas (ICARDA), Addis Ababa, Ethiopia. ${ }^{3}$ Instituto Nacional de Tecnología Agropecuaria (INTA), Bariloche, Argentina. ${ }^{4}$ Agriculture and Natural Resources Research Center, Kerman, Iran. ${ }^{5}$ Animal Science Department, Agriculture College, University of Mashad, Mashad, Iran.

Received: 7 December 2012 Accepted: 7 March 2013

Published: 3 May 2013

\section{References}

Ansari-Renani, HR. 2001. Seasonal follicle cycle and fibre shedding of Raeini cashmere goats. Journal of Pajouhesh, Sazandegi, Ministry of Agriculture, Iran 14(4): 23-25.

Ansari-Renani, HR, Z Ebadi, S Moradi, HR Baghershah, MY Ansari-Renani, and SH Ameli. 2011. Determination of hair follicle characteristics, density and activity of Iranian cashmere goat breeds. Small Ruminant Research 95: 28132.

Ansari-Renani, HR, JP Mueller, B Rischkowsky, SM Seyed Momen, O Alipour, M Ehsani, and S Moradi. 2012. Cashmere quality of Raeini goats kept by nomads in Iran. Small Ruminant Research 104: 10-16.

Badjian, GR, D Ismail, MS Othman, and AA Mehrab. 2011. Simulation model for a nomadic animal production system in southern Iran. Journal of Rangeland Science 1(3): 183-192.

Blench, RM. 2001. Pastoralism in the new millennium. FAO animal production and health paper 150. Rome: FAO.

Brosh, A, A Shkolnilk, and I Choshniak. 1986. Metabolic effects of infrequent drinking and low-quality feed on Bedouin goats. Ecology 67: 1086-1090.

Emadi, MH. 1995. Pastoralists, participation and policy: An action oriented, systemic and participatory approach to improve the relationships between pastoralist nomads, government and natural resources in Iran. Hawkesbury: University of Western Sydney.

Goldstein, M, and C Beall. 1990. Traditional nomadic pastoralism and ecological conservation on Tibet's Northern Plateau. National Geographic Research 6: 139-156. 
Hofmann, RR. 1989. Evolutionary steps of ecophysiological adaptation and diversification of ruminants: a comparative view of their digestive system. Oecologia 78: 443-457.

Maltz, E, A Shkolnik, and S Goring. 1983. Milk production in the desert: The lactating Bedouin goats in natural habitat. Acta Zoologica Fennica 171: 191-193.

Marius, W, DL Naess, Y Drolma, M Per, L Joseph, and J Bardsen. 2004. Nomadic pastoralism in the Aru basin of Tibet's Chang Tang. Rangifer 15: 39-46.

Miller, D. 1998. Nomads of the Tibetan plateau rangelands in western China. Part one: Pastoral History. Rangelands 20: 24-29.

Miller, D. 2000. Tough times for Tibetan nomads in Western China: Snowstorms, setting down, fences, and the demise of traditional nomadic pastoralism. Nomadic Peoples 4: 83-109.

Ministry of Agriculture. 2004. The role of livestock and poultry production on national economy. Tehran: Ministry of Agriculture of Iran.

Randolph, TF, E Schelling, D Grace, CF Nicholoson, JL Leroy, DC Cole, MW Demment, A Omore, J Zinsstag, and M Ruel. 2007. Invited review: The role of livestock in human nutrition and health for poverty reduction in developing countries. Journal of Animal Science 85: 2788-2800.

Rueda, BL, RW Blake, CF Nicholson, DC Fox, LO Tedeschi, AN Pell, ECM Fernandes, JF Valetim, and JC Carmeiro. 2003. Production and economic potentials of cattle in pasture-based systems of the Western Amazon Region of Brazil. Journal of Animal Science 81: 2923-2937.

Sattari, M. 1975. Sheep husbandry in Iran. Tehran: Tehran University.

Schneider, GS. 2012. Market indicators. http://www.gschneider.com/indicators/index.php

Stroebel, A, FJC Swaneopoel, ND Nthakheni, AE Nesamvuni, and GJ Taylor. 2008. Benefits obtained from cattle by smallholder farmers: A case study of Limpopo province, South Africa. Australasian Journal of Experimental Agriculture 48: 825-828.

Vandamme, E, MD D'Haese, S Speelman, and LD D'Haese. 2010. Multifunctionality of livestock keeping in Burundi: Livestock against risk and vulnerability. In The role of livestock in developing communities: Enhancing multifunctionality, ed. FJC Swanepoel, A Stroebel, and S Moyo, 107-122. Wageningen, The Netherlands: CTA.

doi:10.1186/2041-7136-3-11

Cite this article as: Ansari-Renani et al: Nomadic pastoralism in southern Iran. Pastoralism: Research, Policy and Practice 2013 3:11.

\section{Submit your manuscript to a SpringerOpen ${ }^{\circ}$ journal and benefit from:}

- Convenient online submission

- Rigorous peer review

- Immediate publication on acceptance

- Open access: articles freely available online

- High visibility within the field

- Retaining the copyright to your article

Submit your next manuscript at $\boldsymbol{~ s p r i n g e r o p e n . c o m ~}$ 